The Liquidity Coverage Ratio and Security Prices Lucas Marc Fuhrer, Benjamin Müller and Luzian Steiner

SNB Working Papers

$11 / 2016$ 


\section{Legal Issues}

\section{DISCLAIMER}

The views expressed in this paper are those of the author(s) and do not necessarily represent those of the Swiss National Bank. Working Papers describe research in progress. Their aim is to elicit comments and to further debate.

\section{COPYRIGHT@}

The Swiss National Bank (SNB) respects all third-party rights, in particular rights relating to works protected by copyright (information or data, wordings and depictions, to the extent that these are of an individual character).

SNB publications containing a reference to a copyright (@ Swiss National Bank/SNB, Zurich/year, or similar) may, under copyright law, only be used (reproduced, used via the internet, etc.) for non-commercial purposes and provided that the source is mentioned. Their use for commercial purposes is only permitted with the prior express consent of the SNB.

General information and data published without reference to a copyright may be used without mentioning the source. To the extent that the information and data clearly derive from outside sources, the users of such information and data are obliged to respect any existing copyrights and to obtain the right of use from the relevant outside source themselves.

\section{LIMITATION OF LIABILITY}

The SNB accepts no responsibility for any information it provides. Under no circumstances will it accept any liability for losses or damage which may result from the use of such information. This limitation of liability applies, in particular, to the topicality, accuracy, validity and availability of the information.

ISSN 1660-7716 (printed version)

ISSN 1660-7724 (online version)

(C) 2016 by Swiss National Bank, Börsenstrasse 15,

P.O. Box, $\mathrm{CH}-8022$ Zurich 


\title{
The Liquidity Coverage Ratio and Security Prices*
}

\author{
Lucas Marc Fuhrer ${ }^{\dagger}$ \\ Swiss National Bank \\ University of Zürich
}

\author{
Benjamin Müller ${ }^{\ddagger}$ \\ Swiss National Bank \\ University of Basel
}

\author{
Luzian Steiner ${ }^{\S}$
}

Swiss National Bank

August 2016

\begin{abstract}
What is the added value of a security which qualifies as a "high-quality liquid asset" (HQLA) under the Basel III "Liquidity Coverage Ratio" (LCR)? In this paper, we quantify the added value in terms of yield changes and, as suggested by Stein (2013), call it HQLA premium. To do so, we exploit the introduction of the LCR in Switzerland as a unique quasi-natural experiment and we find evidence for the existence of an HQLA premium in the order of 4 basis points. Guided by theoretical considerations, we claim that the HQLA premium is state dependent and argue that our estimate is a lower bound measure. Furthermore, we discuss the implications of an economically significant HQLA premium. Thereby, we contribute to a better understanding of the LCR and its implications for financial markets.
\end{abstract}

JEL Classification: E50, G10, G18, G21, G28

Keywords: Basel III, Liquidity Coverage Ratio, high-quality liquid assets, HQLA premium

\footnotetext{
${ }^{*}$ We are grateful to an anonymous referee for very helpful comments and suggestions. We also thank Morten Bech, Aleksander Berentsen, Benjamin Brunner, Sebastian Dörr, Darrell Duffie, Jaqueson Galimberti, Basil Guggenheim, Richard Hall, Skander van den Heuvel, Matthias Jüttner, Sébastien Kraenzlin, Antoine Martin, Thomas Nellen, Kjell Nyborg, Silvio Schumacher, Jonas Stulz, Paolo Vanini and Benedikt von Scarpatetti as well as the participants of the ECB Workshop on Money Markets and Central Bank Balance Sheets, the KOF Young Swiss Economists Meeting, the European Economic Association Annual Congress 2016, and the SNB Brown Bag Seminar for their useful comments. The views expressed in this paper are those of the authors and do not necessarily represent those of the Swiss National Bank.

${ }^{\dagger}$ E-mail: lucas.fuhrer@snb.ch

${ }^{\ddagger}$ E-mail: benjamin.mueller@snb.ch

${ }^{\S}$ E-mail: luzian.steiner@snb.ch
} 


\section{Introduction}

The recent financial crisis has highlighted how important it is for banks to hold an adequate liquidity buffer in order to withstand severe short-term liquidity shocks. In an effort to strengthen banks' resilience against such shocks, the Basel Committee on Banking Supervision proposed the introduction of an internationally harmonized liquidity standard, the "Liquidity Coverage Ratio" (LCR), as part of the Basel III reforms (Basel Committee on Banking Supervision, 2013). The LCR requires banks to permanently hold an adequate stock of "high-quality liquid assets" (HQLA), consisting of so-called "Level 1" and "Level 2" assets, relative to their expected net cash outflows (NCOF).

In this paper we examine the question as to whether the classification of a security as either Level 1, Level 2, or non-HQLA affects its market price. The change in the market price triggered by the LCR is measured by the yield spread between Level 1 and non-HQLA as well as Level 1 and Level 2 securities respectively and we refer to the change in the spread as the "HQLA premium" as suggested by Stein (2013). Guided by theoretical considerations, we identify the determinants of the HQLA premium. Subsequently, we quantify the HQLA premium for securities denominated in Swiss francs (CHF) empirically. Overall, our research question is inspired by literature suggesting that investors value the liquidity characteristics of a security. ${ }^{1}$

The key findings from our theoretical analysis are as follows: First, the size of the HQLA premium depends on the additional demand for HQLA caused by the LCR requirement, the elasticity of the HQLA supply, and the degree to which banks can reduce their NCOF. For example, if the LCR requires banks to increase their holdings of HQLA securities relative to their preferred portfolio allocation without LCR and if HQLA securities are scarce, the additional demand has a price impact and hence the HQLA premium is positive. Second, the price impact of the LCR requirement depends on the monetary policy environment. In an environment with substantial excess central bank reserves (reserves) and with the interest rate paid on reserves equal to the yield on HQLA securities, the HQLA premium is likely to be negligible.

In our empirical analysis, we consider a comprehensive dataset of homogenous fixed-income securities denominated in euro (EUR) and CHF which used to qualify uniformly as "liquid assets" under the liquidity regulation in Switzerland that was in place before Basel III. We take advantage of the change in the Swiss liquidity regulation which affects securities denominated in CHF and we use securities denominated in EUR as a control group. By using a difference-indifference approach, we exploit the regulatory change as a unique quasi-natural experiment to estimate the HQLA premium.

The introduction of the LCR in Switzerland affects the regulatory treatment of formerly liquid assets in one of the following three ways: the security will be treated the same as it was

\footnotetext{
${ }^{1}$ See Amihud and Mendelson (1986), Ashcraft, Garleanu and Pedersen (2010), Krishnamurthy and VissingJorgensen (2012), Nagel (2016), Chapman, Chiu and Molico (2011) and Nyborg (2015a).
} 
under the former liquidity regulation if it qualifies as a Level 1 asset; it will be subject to a regulatory downgrade if it qualifies as a Level 2 asset or it will no longer have any regulatory value under the LCR if it qualifies as a non-HQLA asset. Consequently, the regulatory change exogenously affects the relative attractiveness of securities and hence their prices.

Empirically, we find that there has been a price differentiation between Level 1, Level 2 and non-HQLA securities before the regulatory change which can be attributed to both the credit and liquidity risk of the corresponding securities. In case of Level 1 and non-HQLA securities and for the sample period under consideration, this price differentiation was in the order of 40 bps. The announcement of the detailed LCR principles reinforced this price differentiation. Our baseline analysis suggests that the HQLA premium is currently in the order of 4 basis points (bps) and the applied robustness checks yield no discrepancies from the baseline results. We argue that the rather small HQLA premium for CHF-denominated securities is primarily due to substantial excess reserves and market interest rates close to the interest rate on reserves, which is a result of the Swiss National Bank's (SNB) monetary policy.

Our findings are relevant in the following ways: First, it is important to recognize that the LCR has introduced an HQLA premium, and that if this premium is non-zero, it affects the equilibrium relationship between asset prices and central bank policy rates (see Bech and Keister (2014) as well as BIS Committee on the Global Financial System (2015)). Hence, to establish the same monetary conditions as prevailed before the regulatory change, central banks may need to target a different level for their policy rates. Moreover, if there is a scarcity of HQLA, banks' demand for reserves will increase to ensure compliance with the LCR. This will force central banks to operate with a larger balance sheet than they would have done in a scenario without LCR (see Debelle (2011)). Furthermore, the existence of an HQLA premium may also affect the choice of monetary policy instruments deployed to exit unconventional monetary policy (see Berentsen, Kraenzlin and Müller (2015)).

Second, our analysis suggests that issuing non-HQLA or Level 2 securities can become more expensive relative to Level 1 securities. Specifically, the LCR creates more favorable issuance conditions for government debt (Level 1) compared to private debt (Level 2 or non-HQLA). Consequently, the LCR incentivizes the production of such assets and may ultimately cause a re-allocation of resources in the real economy (see Nyborg (2015a)).

Third, our results have implications for collateral frameworks of central banks. On the one hand, if central banks accept both HQLA and non-HQLA securities as collateral in their monetary policy operations, banks may increasingly come to rely on central bank funding against non-HQLA securities if haircuts are not adjusted accordingly (HQLA upgrade trade), thereby extending systemic arbitrage, as defined and discussed in Nyborg (2015b) and Nyborg (2015a) and further documented by Fecht, Nyborg, Rocholl and Woschitz (2015). On the other hand, if central banks align their collateral policy to the definition of HQLA, they may reinforce the price differentiation even further. 
The remainder of this paper is structured as follows: Section 2 gives an overview on the literature. Section 3 describes the LCR. Section 4 defines the HQLA premium and presents a simple model for studying its determinants. Section 5 describes the empirical analysis. Section 6 discusses the results. Section 7 reflects on policy implications and finally, Section 8 concludes.

\section{Literature}

This paper is related to three strains of literature. First, our paper is related to the literature which studies the impact of the LCR in a broad sense. Based on a theoretical model, Bech and Keister (2014) study the impact of the LCR in jurisdictions with a scarcity of HQLA. They show that the LCR can affect security prices and describe how the introduction of a committed liquidity facility, i.e. a standing facility offered by the central bank where non-HQLA securities can be upgraded to HQLA securities, limits the price impact of the LCR on security prices and thus sets an upper bound for the HQLA premium. ${ }^{2}$ Related to this, Stein (2013) suggests that the HQLA premium is state-dependent. In other words, if HQLA securities are in ample supply, the HQLA premium is expected to be low, whereas if HQLA securities are scarce, the HQLA premium is expected to be large. Banerjee and Mio (2014) analyze the impact of the liquidity regulation on banks' balance sheets and find that banks subject to the LCR have adjusted the composition of their assets towards HQLA. Other related papers are Bonner (2012) and Bonner and Eijffinger (2012) which analyze the impact of the "Dutch liquidity ratio" on banks' retail and interbank lending conditions.

Second, our paper is related to literature on the interaction between the safety and liquidity characteristics of an asset and its price. Krishnamurthy and Vissing-Jorgensen (2012) show that the yield spread between US corporate bonds and US Treasuries is high in periods with a relative scarcity of US Treasuries and vice versa. The authors thus provide evidence that investors value the liquidity and credit quality of US Treasuries as a safe asset and demonstrate that this premium is a function of the supply of these assets. Along the same line of argumentation, Carlson, Duygan-Bump, Natalucci, Nelson, Ochoa, Stein and Van den Heuvel (2014) show that this premium might even increase with the introduction of new regulatory requirements such as the LCR. Fender and Lewrick (2013) document increased demand for high-quality collateral due to regulatory initiatives (e.g. collateral requirements in derivatives markets as well as Basel III liquidity and capital regulations) and discuss endogenous adjustments in the supply. Nagel (2016) argues that the liquidity premium of near-money assets such as US Treasury Bills does not only depend on the supply of liquid assets but rather on the opportunity cost of holding money, which is a function of the level of short-term interest rates. That is, if short-term

\footnotetext{
${ }^{2}$ The committed liquidity facility is part of the "alternative liquidity approaches" (ALA options) proposed by the Basel Committee on Banking Supervision (BCBS) and discussed in more detail in Section 6. Committed liquidity facilities have been implemented by the Reserve Bank of Australia and the South African Reserve Bank (see Bech and Keister (2014)).
} 
interest rates are high, investors are willing to pay a larger liquidity premium for near-money assets than with low short-term interest rates. Finally, Nyborg and Östberg (2014) show that the demand for liquidity generally affects financial market activity. As funding stress rises, market participants sell relatively more liquid assets. Besides these empirical analyses, there exists a large theoretical literature on the interaction of the liquidity characteristics of an asset and its price. Among others, references are Kiyotaki and Moore (2005) and studies in the tradition of Lagos and Wright (2005), including Lagos (2010), Lagos and Rocheteau (2009), Rocheteau et al. (2015) and Williamson (2012).

Third, our paper is related to the literature dealing with the impact of haircuts on security prices. For instance, Ashcraft et al. (2010), Chapman et al. (2011) and Nyborg (2015a) argue that haircuts applied in central bank open market operations affect the market price of securities and consequently investment decisions in the real economy, since the larger the haircut, the smaller the potential to use the collateral to borrow from the central bank. In this context, Bindseil and Papadia (2006) as well as Buiter and Sibert (2005) estimate the so-called "central bank eligibility premium" (CBEP). The CBEP is the yield differential between two identical securities where one security is eligible in central bank operations and the other one is not. The authors find little evidence for a significant CBEP but they argue that the premium is likely to be state-dependent. Bartolini, Hilton, Sundaresan and Tonetti (2010) show that there is a price differentiation in the US repo market by security type which varies significantly over time. The authors show that in times of stress, if reserves are scarce or if the central bank has a narrow collateral framework (i.e. only accepts few securities in its monetary policy operations), the price differentiation by security type is large, whereas if there is an ample supply of reserves or if market stress is not elevated, the differentiation is small.

\section{Liquidity Coverage Ratio}

The BCBS proposed the introduction of the LCR as an internationally harmonized liquidity standard in the aftermath of the global financial crisis as part of the Basel III reforms designed to enhance banks' resilience against short-term liquidity shocks (Basel Committee on Banking Supervision, 2013). ${ }^{3}$ The LCR requires banks to hold an adequate stock of HQLA relative to their expected NCOF over a 30-day stress period. As a rule, NCOF must be covered by HQLA in the same currency. The LCR is calculated as the ratio of HQLA to NCOF and must be greater than or equal to one (see Equation 1). The LCR was phased-in step-wise from 1 January 2015. That is, the LCR requirement was $60 \%$ in 2015 and it rises by 10 percentage points every year until it reaches $100 \%$ in 2019.

\footnotetext{
${ }^{3}$ Note that the first LCR-proposal was published in December 2010 (Basel Committee on Banking Supervision, 2010).
} 


$$
\frac{H Q L A}{N C O F} \geq 1
$$

HQLA assets are subdivided into two categories: Level 1 and Level 2 assets. Level 1 assets include reserves, marketable government and central bank securities as well as securities issued by supranational organizations or multilateral development banks exhibiting the highest liquidity and credit quality. ${ }^{4}$ The market value of Level 1 assets counts towards HQLA without being subject to a haircut, reflecting the assumption that these assets can be liquidated without significant losses in a short period of time even under severe stress. Consequently, these assets have the highest regulatory value.

Level 2 assets include the same types of securities as Level 1, however, their credit quality is lower. ${ }^{5}$ Additionally, Level 2 assets include corporate debt securities issued by non-financial institutions and covered bonds. Level 2 assets count towards HQLA with a 15\% haircut applied to the market value of the assets, reflecting the assumption that these assets might only be liquidated with an average loss of $15 \%$ in a severe stress scenario. Furthermore, the total stock of HQLA of a bank may contain no more than $40 \%$ Level 2 assets. ${ }^{6}$ Assets that do not qualify as HQLA have no regulatory value under the LCR.

NCOF are the expected cash outflows minus the expected cash inflows over a 30-day stress scenario. Expected cash outflows are calculated by assigning weighting parameters to different bank liabilities. As a rule, the faster a liability is expected to run off, the higher its weighting parameter. Expected cash inflows capture a limited amount of contractual inflows from outstanding contracts within a 30-day period.

\section{HQLA premium}

In this section, we define the term "HQLA premium" and identify its determinants. To do so, we set up a simple model which is motivated by Bech and Keister (2014). Although the model is very simple, it is sufficiently rich to formulate hypotheses which we then assess empirically.

\subsection{Definition}

The HQLA premium is defined as the change in the yield spread between Level 1 and non-HQLA as well as Level 1 and Level 2 securities which can only be attributed to their differing regulatory treatment (see Figure 1). The HQLA premium is expected to be positive if the LCR is binding

\footnotetext{
${ }^{4}$ These securities are assigned a $0 \%$ risk weight under Basel II (see Basel Committee on Banking Supervision (1988)).

${ }^{5}$ These securities are assigned a $20 \%$ risk weight under Basel II (see Basel Committee on Banking Supervision (1988)).

${ }^{6}$ National authorities have the discretion to include additional security categories in the Level 2 definition, so-called "Level $2 \mathrm{~b}$ " assets. A higher haircut is applied to Level $2 \mathrm{~b}$ assets and the stock of HQLA may contain no more than $15 \%$ Level $2 \mathrm{~b}$ assets.
} 
(permanently or temporarily) or binds in expectation, as banks are either forced to acquire additional HQLA securities, which drives up the price/lowers the yield for a given supply and for given NCOF, or banks are only willing to offer HQLA securities at a higher price/lower yield. We expect the HQLA premium of Level 1 compared to non-HQLA securities to be larger than the HQLA premium for Level 1 compared to Level 2 securities. In the subsequent theoretical analysis, the focus is on the HQLA premium comparing Level 1 and non-HQLA securities.

Figure 1: HQLA premium

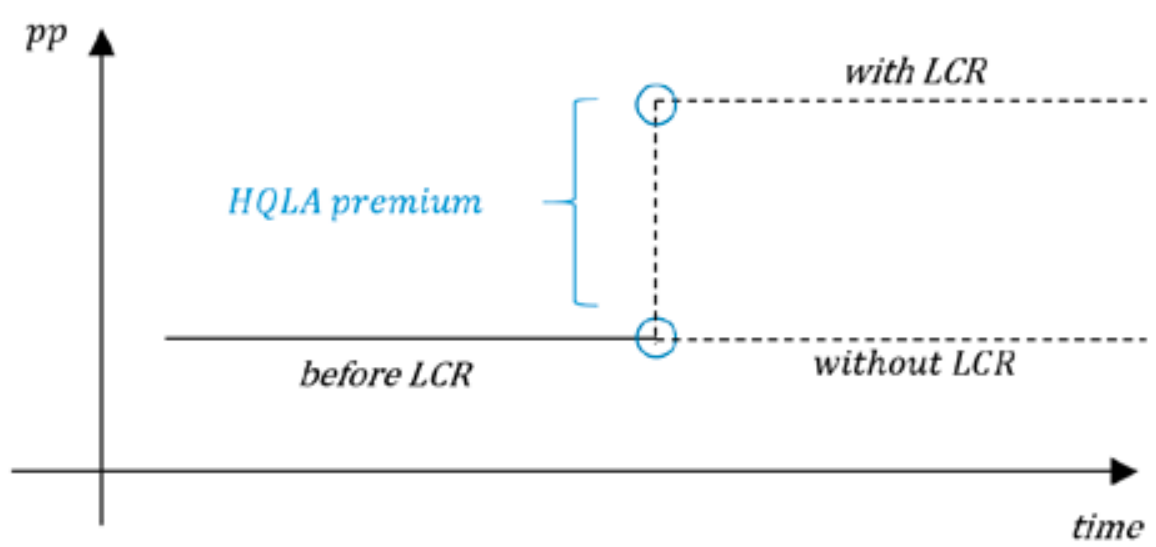

Figure 1 illustrates schematically the HQLA premium as an increase in the spread between Level 1 and non-HQLA securities caused by the LCR.

Empirically, we observe a yield differentiation between Level 1, Level 2 and non-HQLA securities in the absence of the LCR. This yield differentiation can be attributed to both the credit and liquidity risk of the corresponding securities and is documented in the empirical analysis below. With the LCR in place, and based on the intuition outlined, we expect this yield spread to widen by the HQLA premium, with the size of the HQLA premium depending on several determinants studied below.

\subsection{Theory}

Consider an economy which is populated by a continuum of risk-neutral banks and non-banks. Banks are profit maximizing, operate in frictionless and perfectly competitive markets and take prices as given. There is no uncertainty and we disregard the costs of operating a bank.

The model period is divided into two stages. In stage 1 , banks are funded with deposits $\bar{D}$ and equity $\bar{E}$ which are initially held as reserves $R$. The funding structure is determined outside of the model and hence is exogenous for banks. In stage 2, a securities market opens and banks can re-adjust their portfolio using reserves. They can either purchase HQLA securities which are risk-free and earn $i_{H Q L A}$ or purchase risky non-HQLA securities which earn $i_{n o n-H Q L A}$. Banks can also keep reserves which are remunerated at $i_{r}$ by the central bank. The central bank targets 
a risk-free interest rate which corresponds to the yield of HQLA securities.

All securities are initially held by non-banks. ${ }^{7}$ The total stock of HQLA and non-HQLA securities is determined exogenously or can be thought of as being fixed in the short-run. The stock of non-HQLA securities is assumed to be large whereas the stock of HQLA securities is small. To simplify matters, we assume that non-banks can offer an unlimited amount of nonHQLA securities. The supply (demand) curve of both security types is assumed to be continuous and weakly decreasing (increasing) in the yield. In other words, non-banks are willing to supply securities if the yield on them is sufficiently low (i.e. the price is sufficiently high) and banks are willing to buy securities if the yield on them is sufficiently high (i.e. the price is sufficiently low).

Non-banks demand a risk premium $\tau$ to compensate them for the credit and liquidity risk associated with holding non-HQLA securities. Hence, non-banks are only willing to supply HQLA securities at a yield which is smaller than or equal to $i_{H Q L A}^{n o n-b a n k s}$ and which is lower than the yield at which non-banks are willing to supply non-HQLA securities, denoted as $i_{n o n-H Q L A}^{\text {non-banks }}$. Non-banks are indifferent between supplying HQLA and non-HQLA securities if the yield spread is equal to $\tau$.

In the absence of the LCR, banks are only willing to hold HQLA securities if the yield is greater than or equal to $i_{H Q L A}^{b a n k s}$ and, due to credit and liquidity risk considerations, they are only willing to hold non-HQLA securities if the yield is greater than or equal to $i_{n o n-H Q L A}^{\text {banks }}$. Banks are indifferent between acquiring HQLA and non-HQLA securities if the yield spread is equal to $\tau$ and banks strictly prefer to hold securities instead of reserves as long as $i_{H Q L A}>i_{r}$. Below, we discuss possible equilibrium allocations with and without LCR as well as the interaction between monetary policy and the HQLA premium.

Proposition 1. Without LCR, the pricing of HQLA securities and non-HQLA securities differs due to credit and liquidity risk considerations. In equilibrium, it must hold that $i_{H Q L A}+\tau=$ $i_{\text {non-HQLA }}$.

Without LCR, banks are indifferent between holding HQLA and non-HQLA securities if the above proposition applies. Any deviation from this relationship would immediately be arbitraged away. In equilibrium, banks' asset side has the following composition: reserve holdings are zero as long as $i_{r}<i_{H Q L A}, H Q L A \geq 0$, non- $H Q L A \geq 0$ and $H Q L A+$ non- $H Q L A=\bar{D}+\bar{E}$. Figure 2 shows a possible equilibrium allocation without LCR, where $i_{r}<i_{H Q L A}$.

Introducing the LCR requires banks to cover NCOF with HQLA securities or reserves. Here, the only component of NCOF is represented by deposits $\bar{D}$ which are weighted by the LCR outflow parameter $\theta \leq 1$. Hence, the LCR restriction in our model can be expressed as follows:

\footnotetext{
${ }^{7}$ As documented in Arslanalp and Tsuda (2014) this is not an unrealistic assumption. They show that more than $80 \%$ of the outstanding volume of Swiss government debt was held by non-banks at the end of 2013. For other advanced economies, the fraction of government debt held by non-banks is of similar magnitude.
} 
Figure 2: Equilibrium without LCR

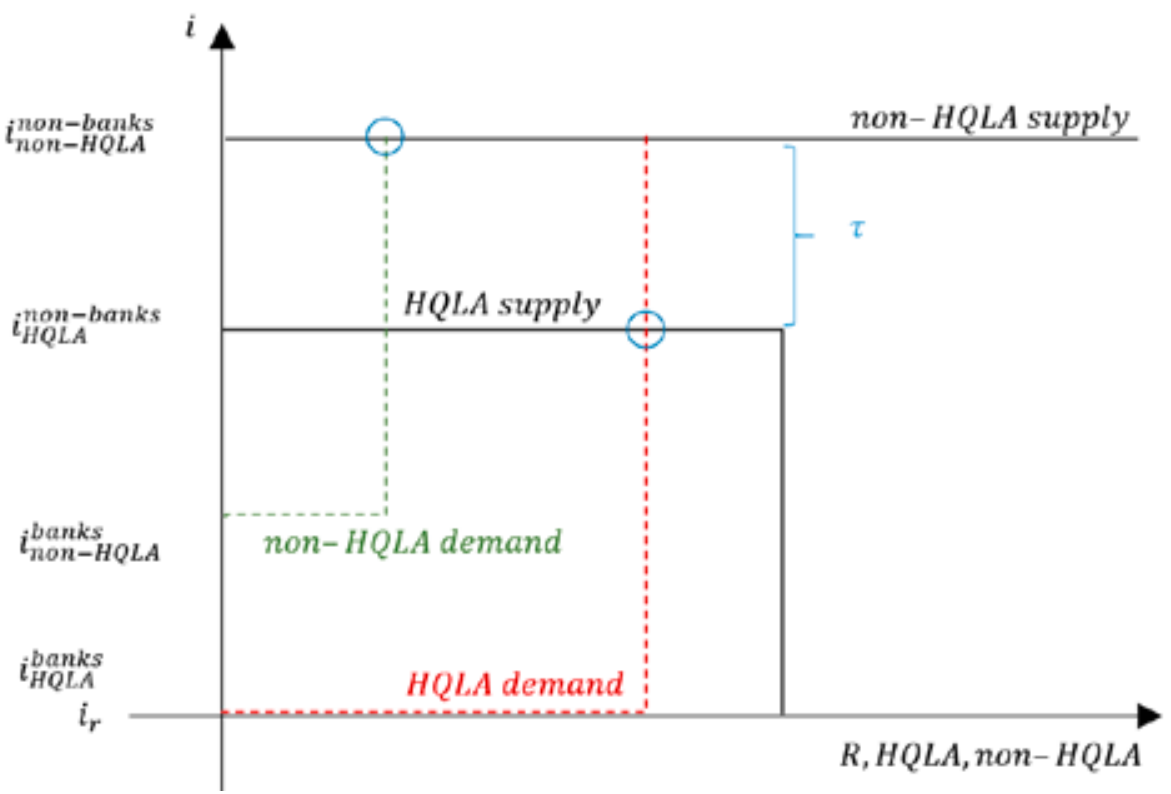

Figure 2 shows a possible equilibrium allocation without LCR. Quantities are depicted on the x-axis and yields on the y-axis. Solid lines represent supply curves and dotted lines demand curves. The price differentiation between HQLA and non-HQLA securities is reflected by the risk premium $\tau$.

$$
\frac{H Q L A+R}{\theta \bar{D}} \geq 1
$$

If the LCR is non-binding as banks already hold sufficient HQLA assets, no portfolio adjustment has to take place. If the LCR is binding, banks need to acquire additional HQLA securities or reserves and, as long as $i_{r}<i_{H Q L A}$, banks strictly prefer to hold additional HQLA securities instead of reserves. There are two cases for the equilibrium allocation if the LCR is binding. Both cases are illustrated in Figure 3.

Case 1 represents an economy where the stock of HQLA is sufficiently large that banks can acquire additional HQLA securities without price impact. In this case, the HQLA demand curve crosses the HQLA supply curve in a region where the supply is elastic and hence $i_{n o n-H Q L A}-$ $i_{H Q L A}=\tau$ still holds in equilibrium.

Case 2 represents an economy where the stock of HQLA securities is insufficient relative to the required stock of HQLA securities. In this case, the HQLA demand curve crosses the HQLA supply curve in a region where the supply is inelastic and the market-clearing HQLA yield is lower than without LCR.

Proposition 2. If the LCR is binding and if the supply of HQLA securities is not fully elastic, an $H Q L A$ premium $\mu$ is added to the existing yield differentiation between $H Q L A$ and non-HQLA securities. In equilibrium it must hold that $i_{\text {non-HQLA }}-i_{H Q L A}=\tau+\mu$. 
Figure 3: Equilibrium with LCR

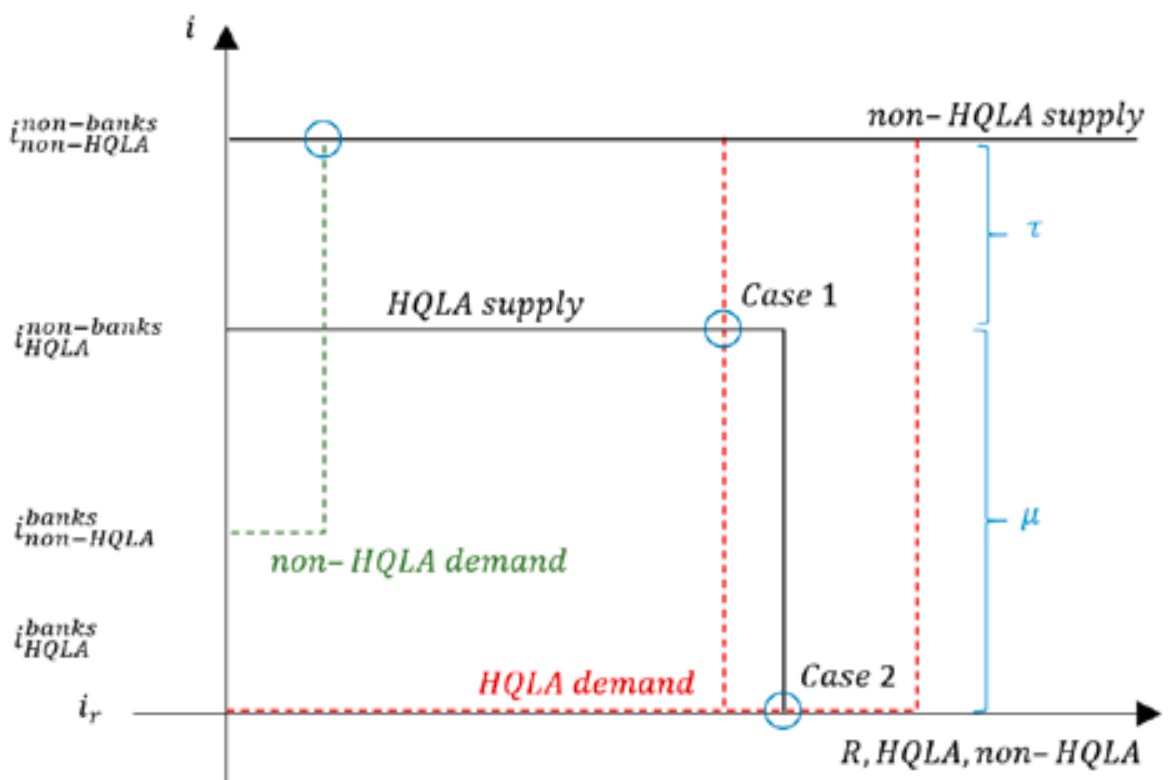

Figure 3 shows two possible equilibrium allocations with a binding LCR. Quantities are depicted on the $\mathrm{x}$-axis and yields on the y-axis. Solid lines represent supply curves and dotted lines demand curves. In Case 1, the stock of HQLA securities is sufficiently large that banks can acquire additional HQLA securities without price impact and hence the price differentiation remains unchanged compared to the equilibrium without LCR. In Case 2, the demand for HQLA cannot be satisfied by the existing stock of HQLA. Hence the price for HQLA securities gets bid up (lower yield), thereby enforcing the existing price differentiation by introducing the HQLA premium $\mu$.

In equilibrium, banks' asset side has the following composition: $R \geq 0, H Q L A \geq 0$, non-HQLA $\geq 0$ and $R+H Q L A+$ non-HQLA $=\bar{D}+\bar{E}$ as well as the LCR condition $H Q L A+R \geq$ $\theta \bar{D}$ must hold. Note that in the equilibrium allocation of Case 2, shown in Figure 3, $R$ must strictly be greater than zero, as the stock of HQLA securities is insufficient for all banks to fulfill the LCR with HQLA securities only.

The implications of Proposition 2 replicate nicely the argument by Stein (2013) that the HQLA premium is stated dependent. That is, if HQLA securities are in ample supply, the HQLA premium is expected to be low, whereas if HQLA securities are scarce, the HQLA premium is expected to be high. Increasing the LCR requirement over time (LCR phase-in) or increasing the parameter $\theta$ requires banks to hold additional HQLA which may widen the HQLA premium further. Moreover, a change in the supply of HQLA also affects the HQLA premium. ${ }^{8}$

The equilibrium allocation of Case 2, shown in Figure 3, is relevant for central banks in three ways: First, remember that the central bank targets a risk-free rate (i.e. the yield of HQLA securities in the model). Without changing its monetary policy stance, $i_{H Q L A}$ can

\footnotetext{
${ }^{8}$ Note that in practice, $\bar{E}$ and $\bar{D}$ are not determined exogenously. In order to reduce the required holdings of HQLA, banks could shrink their balance sheet by reducing their deposits and thus selling non-HQLA securities (de-leveraging). At some point, the remaining stock of HQLA securities is such that banks can fulfill their LCR without additional demand for reserves.
} 
Figure 4: Equilibrium with LCR and floor system of monetary policy

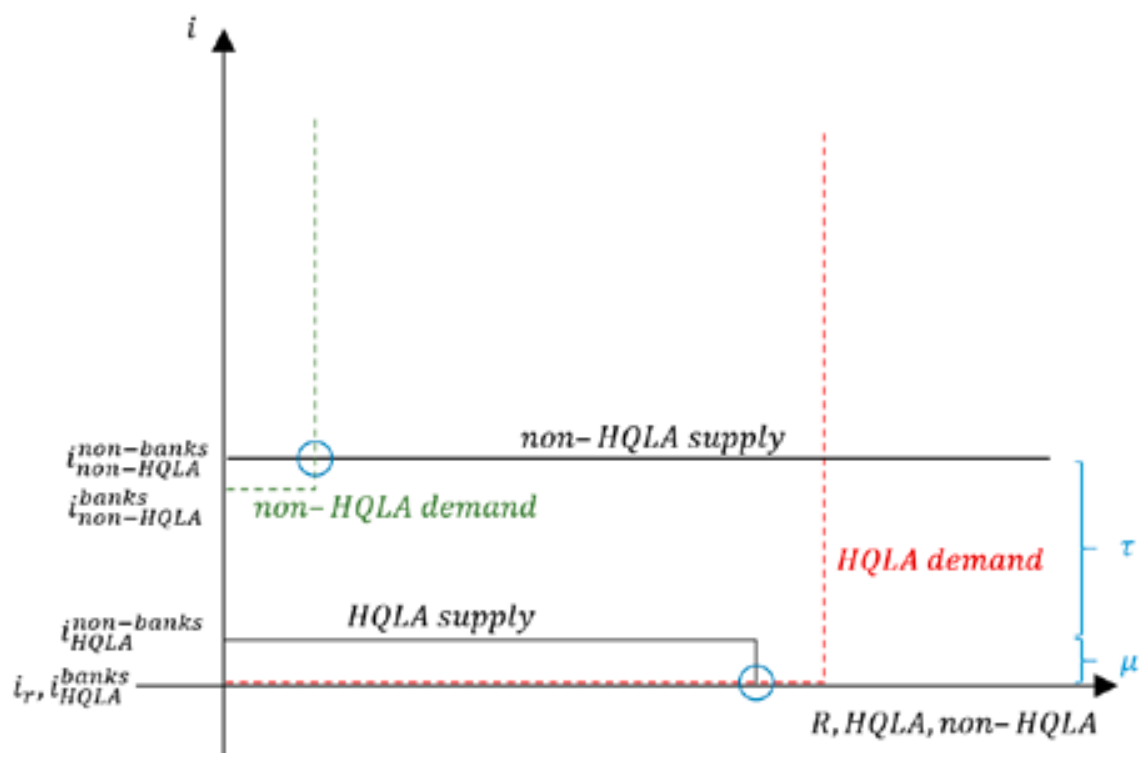

Figure 4 shows the equilibrium allocation with a binding LCR in an environment where the risk-free rate $i_{H Q L A}$ is close to the interest rate on reserves $i_{r}$. Quantities are depicted on the x-axis and yields on the y-axis. Solid lines represent supply curves and dotted lines demand curves. Although there is a shortage of HQLA securities, the HQLA premium $\mu$ is close to zero.

change due to the introduction of the LCR. Hence, central banks need to take the HQLA premium into consideration when targeting a certain risk-free rate. Second, in case of insufficient HQLA securities, central banks may be forced to operate with a larger balance sheet than they would in an environment without LCR as they face additional demand for reserves from banks. ${ }^{9}$ Third, if the central bank reduces the risk-free rate, and hence the yield on HQLA securities, to the level of the interest rate it pays on reserves (essentially a floor system of monetary policy implementation), banks become indifferent between holding reserves and HQLA securities. In this case, the HQLA premium is zero, irrespective of whether HQLA securities are scarce (see Figure 4). This is in line with Nagel (2016) who documents that the liquidity premium of nearmoney assets such as US Treasury Bills decreases with lower short-term interest rates and thus lower opportunity cost of holding money (here reserves).

Proposition 3. If $i_{H Q L A}=i_{r}$, the $H Q L A$ premium $\mu$ is zero as banks are indifferent between holding reserves or HQLA securities in order to fulfill the LCR requirement.

\footnotetext{
${ }^{9}$ The second implication is not a direct outcome of the model as banks hold their endowment in the form of reserves and as long as $\bar{E} \geq 0$ and $\theta \leq 1$ there are always sufficient reserves to ensure that every bank is able to fulfill its LCR. In reality, due to leverage, the consolidated balance sheet of the banking system is only partially covered by reserves.
} 


\subsection{Hypotheses}

Based on the theoretical considerations above, we can derive the following three hypotheses, which we subsequently assess empirically.

Hypothesis 1: Without LCR, the pricing of HQLA securities and non-HQLA securities differs due to credit and liquidity risk considerations.

Hypothesis 2: If the LCR is a binding constraint and if the supply of HQLA securities is not fully elastic, an HQLA premium is added to the existing yield differentiation between HQLA and non-HQLA. The size of the HQLA premium depends on the additional HQLA demand caused by the LCR, the elasticity of the HQLA supply and the degree to which banks can reduce their NCOF.

Hypothesis 3: If the yield on HQLA securities is equal to the interest rate the central bank pays on reserves and banks are holding excess reserves the HQLA premium is zero as banks are indifferent between holding reserves and HQLA securities in order to fulfill the LCR.

\section{$5 \quad$ Empirical analysis}

This section empirically assesses the three hypotheses outlined in the previous section. To do so, we make use of the change in the liquidity regulation in Switzerland which serves as a quasinatural experiment and allows us to quantify the HQLA premium. The following paragraphs are structured as follows: First, we discuss the former liquidity regulation and highlight the main differences vis-à-vis the LCR. Second, we describe the dataset used for our empirical analysis. Third, we provide descriptive statistics on our data. Fourth, we describe our empirical strategy and discuss the results. Finally, we subject our regression analysis to several robustness checks.

\subsection{Institutional background}

In Switzerland, banks were already subject to liquidity requirements before the introduction of the LCR (Federal Council, 2003). The former liquidity regulation, which dated back to 1988, required banks to cover at least $33 \%$ of specific short-term liabilities with liquid assets, the equivalent of HQLA under the LCR. Liquid assets were eligible for the fulfillment of the liquidity regulation uniformly and without haircut. Among others, securities eligible in SNB repo transactions were deemed to be liquid assets.

From a methodological perspective, the LCR and the former liquidity regulation are fairly similar, as both regulations require banks to hold a certain stock of liquid assets to cover potential liquidity outflows. However, the former liquidity regulation is considered as less stringent as it was not parameterized to the stress periods experienced during the financial crisis, allowed for 
currency mismatches between outflows and liquid assets and was not internationally harmonized (FINMA, 2014). ${ }^{10}$

In Switzerland, the former liquidity regulation was replaced upon publication of the LCR legislative principles by the Swiss Federal Council on 25 June 2014 (Federal Council, 2014) and the LCR eventually came into effect on 1 January 2015. On 7 July 2014, the Swiss Financial Market Supervision Authority (FINMA) published detailed information on the legislative principles and a list published by the SNB was available with a classification of all SNB-eligible securities under the new liquidity regulation, defining which securities belong in which category: Level 1, Level 2, or non-HQLA (FINMA, 2014). ${ }^{11}$ A comprehensive list covering virtually all CHF-denominated HQLA securities has thus been publically available and became widely used by banks to manage their stock of HQLA. ${ }^{12}$ Throughout the paper we shall be referring to the FINMA's 7 July 2014 announcement as the "regulatory change", since we believe that the 7 July 2014 has attracted more attention among banks than the publication of the legislative principles. ${ }^{13}$

Under the LCR, CHF-denominated securities that formerly qualified as liquid assets are affected in one of the following three ways: First, the regulatory treatment of a security remains unchanged if it qualifies as a Level 1 asset; such assets count towards the liquidity buffer with $100 \%$ of their market value. Second, a security is subject to a regulatory downgrade if it qualifies as a Level 2 asset. The regulatory treatment of Level 2 assets differs from that under the former liquidity regulation as Level 2 assets may only be counted towards HQLA with a $15 \%$ haircut and the total stock of HQLA may contain no more than $40 \%$ Level 2 assets (cap). Third, a security no longer has any regulatory value under the LCR if it qualifies as non-HQLA; it is therefore subject to regulatory exclusion. ${ }^{14}$

\footnotetext{
${ }^{10}$ Since mid-2010, an additional liquidity regime, very similar to the LCR, has been introduced for systemically important banks in Switzerland. Compared to the LCR, the stress scenario underlying the estimates for the outflow parameter is more severe in the Swiss liquidity regime. However, the definition of the liquidity buffer is broader, less focused on government bonds and most importantly not CHF specific (see Nixon, Portes and Danthine (2013)).

${ }^{11}$ This list was available as of 2 May 2014, already. With the publication of the detailed information on the legislative principles, a reference to this list was made by FINMA and the classification became widely used by market participants. Moreover, a press release by the SNB as of 7 July 2014 also referred to this list.

${ }^{12}$ This list was published in light of a change in the SNB's collateral policy. With this adjustment, non-HQLA securities were excluded from the list of SNB-eligible securities, as of 1 January 2015. By aligning its collateral policy to the LCR, the SNB ensured that collateral eligible in its monetary policy operations continues to be viewed as a liquid asset from a regulatory perspective (Swiss National Bank, 2014). For non-HQLA securities, the HQLA premium might also include a CBEP. In Switzerland, the CBEP is currently expected to be very low or close to zero for CHF-denominated securities for several reasons. As a result of the SNB's unconventional measures, the banking system is currently operating in a structural liquidity surplus and thus not dependent on central bank funding. Given the banks' liquidity situation, the SNB discontinued its liquidity-providing open market operations in May 2010 and is currently only operating its "liquidity-shortage financing facility" - an instrument that has been used rarely in previous years (see SNB accountability reports). Furthermore, as a result of the banks' liquidity situation, funding stress in the Swiss banking system is currently at low levels (see, for example, the Swiss franc Libor-OIS spread).

${ }^{13}$ Note that our results hold independently of the choice of the regulatory treatment date (see robustness checks).

${ }^{14}$ Consider, for instance, a bank that holds three types of assets, each with a value of one and all of which qualify as liquid assets. Under the former liquidity regulation, the stock of liquid assets would have amounted
} 


\subsection{Data}

The dataset used in the analysis comprises securities which were SNB-eligible in 2014 and hence were deemed to be liquid assets under the former Swiss liquidity regulation. ${ }^{15}$ SNB-eligible securities are homogenous securities that fulfill strict requirements with regard to the credit and liquidity quality. Eligible securities are fixed-rate, floating-rate or zero-coupon interest-bearing securities denominated in CHF as well as EUR, US Dollar, Pound Sterling, Danish Krone, Swedish Krona and Norwegian Krone. These must be issued by central banks, public-sector entities, international or supranational institutions or private-sector entities (including covered bonds and Swiss Pfandbriefe). As a rule, all eligible securities must be marketable and traded on a recognized stock exchange or a representative market that publishes price data on a regular basis.

Standards with respect to the rating and liquidity of securities are high. Eligible securities must have a minimum long-term rating of AA- (where the second-best rating of Standard \& Poor's, Moody's and Fitch is decisive) and a volume at issuance equivalent to at least CHF 1 billion (bn) for non-CHF-denominated securities and CHF 100 million (mn) for securities denominated in CHF. ${ }^{16}$ By the end of 2014, about 2,800 different securities with a combined worth of CHF 9,650 bn were SNB-eligible, of which CHF 7,835 bn $(81.2 \%)$ were classified as Level 1 securities, CHF 1,580 bn as Level 2 securities (16.4\%) and 235 bn as non-HQLA securities $(2.4 \%)$. As the list of SNB-eligible securities is subject to daily modifications due to new issues, redemptions or exclusions, small fluctuations in the overall volume do occur.

To quantify the HQLA premium, we collected daily price information (mid prices) as well as further ISIN specific characteristics for all SNB-eligible securities from Bloomberg. To check whether the empirical analysis is not relying on theoretical security prices calculated by Bloomberg, we inspected Bloomberg's pricing source ex-post (i.e. in 2015). For the vast majority of the securities we use, the price information we found are based on actual transactions

to three. Now assume that the three types of assets correspond to the HQLA categories such that there is one unit of Level 1 assets, one unit of Level 2 assets and one unit of non-HQLA assets. Under the LCR, the stock of HQLA would amount to 1.67. This is because one unit of Level 1 assets counts in full. Due to the $15 \%$ haircut and the $40 \%$ cap, only 0.67 of the Level 2 assets qualifies as HQLA. The one unit of non-HQLA assets no longer counts towards HQLA, at all.

${ }^{15}$ This subsection gives a brief overview of the SNB's collateral framework and draws on Swiss National Bank (2015). For more details, see, for example, Fuhrer, Guggenheim and Schumacher (2016).

${ }^{16}$ Note that until 2015, the rating threshold was A for securities denominated in CHF. 
or executable quotes. ${ }^{17}$ The HQLA attribute is based on SNB's HQLA classification. ${ }^{18}$

Given our focus on the regulatory change, the following adjustments to the set of SNB-eligible securities have been made. First, only securities denominated in EUR and CHF are considered, for three reasons: (i) EUR and CHF securities fulfill the crucial parallel trend assumption for our econometric approach to measuring the impact of the regulatory change (discussed below); (ii) only securities denominated in these two currencies span all HQLA attributes (Level 1, Level 2 and non-HQLA) - a precondition for the empirical analysis; and (iii) roughly $80 \%$ of all SNB-eligible securities are denominated in these two currencies. With these modifications, our dataset contains 2,756 different securities for the year 2014. Second, to ensure a fixed dataset, only securities that were SNB-eligible throughout the observation period are considered. Securities that were issued during the observation period are therefore not part of the data sample. Moreover, we exclude securities that mature before 1 February 2015, since they do not affect the LCR and should in turn not be affected by the new regulation. ${ }^{19}$ This reduces the sample size to 1,807 securities. Third, we exclude 27 securities for which the HQLA attribute has changed during the observation period. ${ }^{20}$ Fourth, we only consider zero or fixed-coupon securities and therefore excluded 120 securities with variable coupon payments. ${ }^{21}$ Consequently, the final dataset comprises 1,660 securities and includes daily price information for each security for the year 2014. Moreover, for each security the currency of denomination, maturity, coupon, HQLA attribute, volume at issuance and daily yield to maturity are known. ${ }^{22}$

\subsection{Descriptive statistics}

Below, we present descriptive statistics to give an overview of the dataset used in the empirical analysis. Furthermore, the descriptive statistics provide valuable insights for Hypothesis 1.

Number of securities: Table 3 shows the distribution of the securities according to currency

\footnotetext{
${ }^{17}$ In the ex-post analysis, executable prices from market participants (quoted bid and ask prices as well as executable volumes) or prices from stock exchanges are available for about $99 \%$ of all SNB-eligible securities denominated in EUR and CHF considered in the empirical analysis. Compared to ECB-eligible securities, this ratio is high. Based on a real-time analysis, Nyborg (2015a) shows that around $77 \%$ of all ECB-eligible securities have only theoretical prices ( $17 \%$ if counted by volume). Potential reasons for this large difference may include: (i) the fact that the SNB only considers marketable securities, for which prices are published on a regular basis; (ii) the fact that the SNB only considers high-quality and liquid securities whereas the ECB collateral framework allows for a broader range of securities; (iii) the number of eligible securities, which is relatively small in the case of the SNB (around 2,800 securities) and large in the case of the ECB (around 35,000 securities) as documented by Nyborg (2015a).

${ }^{18}$ For more details, see www.snb.ch / Financial markets / Monetary policy operations / Collateral eligible for SNB repos

${ }^{19}$ Securities that mature within 30 days affect the stock of HQLA and the NCOF to the same extent and thus there is no significant LCR impact.

${ }^{20}$ The HQLA classification for those securities was revised between July 2014 and December 2014 due to respecifications with respect to HQLA requirements by the regulatory authority.

${ }^{21}$ These are floating rate notes, variable rate notes as well as inflation protected bonds.

${ }^{22}$ Throughout the paper, we analyze security yields (yield to maturity) and not prices. The yield accounts for the security's current market price, the coupon and the residual maturity.
} 
of denomination, securities' duration (Macaulay duration) and HQLA attribute. The number of securities denominated in CHF and EUR are roughly balanced, with 778 securities denominated in CHF and 848 securities denominated in EUR. The distribution of Level 1, Level 2 and non-HQLA securities by count is $48 \%, 46 \%$ and $6 \%$ (by volume $81 \%, 17 \%$ and $2 \%$ ) for EUR-denominated securities and $26 \%, 55 \%$ and $19 \%$ (by volume $38 \%, 47 \%$ and $15 \%$ ) for CHFdenominated securities, respectively. The lower share of Level 1 securities denominated in CHF evaluated by count and volume reflects the fact that, compared to the euro area, Switzerland has relatively few government bonds outstanding. The low share of EUR denominated Level 1 securities when evaluated by count compared to share when evaluated by outstanding volume is due to the fact that the issuance volume of Level 1 securities is larger than for Level 2 or non-HQLA securities.

Credit quality: Figure 7 and 8 show the distribution of securities according to their second best credit rating (as defined above) for Level 1, Level 2 and non-HQLA securities denominated in CHF and EUR. It confirms that the different HQLA categories have different credit qualities. In particular, there is a distinct difference in the average credit quality of Level 1 and nonHQLA securities which is prevalent for securities denominated in CHF as well as EUR. For both currencies, most Level 1 and Level 2 securities have a "AAA" rating whereas most non-HQLA securities have a "AA-" rating. Overall, the credit quality of the securities in our dataset is very high.

Outstanding volume: The total outstanding volume of EUR-denominated securities amounts to EUR 3,870 bn and is considerably larger than the outstanding volume of CHF-denominated securities, which amounts to CHF 326 bn (see Table 3). Figure 9 shows the average outstanding volume for Level 1, Level 2 and non-HQLA securities by currency of denomination. On average, EUR-denominated securities have a substantially higher outstanding volume than CHF-denominated securities. ${ }^{23}$ Moreover, the figure shows that, irrespective of the currency of denomination, Level 1 securities have the highest outstanding volume followed by Level 2 and non-HQLA securities.

Price variation: To analyze the price variation of security prices, we calculated the standard deviation of each security's daily price changes as well as the maximum price decline within a 30-day window for each security in the observation period 9 January 2014 to 17 December 2014. The second measure follows closely the 30-day LCR stress scenario (Basel Committee on Banking Supervision (2013), para 52). The findings of the analysis of price variation are as follows: First, price changes were fairly moderate in 2014. Moreover, as yields of securities

\footnotetext{
${ }^{23}$ This large difference between CHF and EUR securities is, at least in part, due to the fact that the SNB-eligible securities must have a volume at issuance equivalent to CHF 1 bn if denominated in foreign currencies and $\mathrm{CHF}$ $100 \mathrm{mn}$ if denominated in $\mathrm{CHF}$.
} 
were mostly decreasing over the sample period, prices mostly increased and hence the observed price declines are fairly small (Table 5). Second, the price variation is generally increasing in the duration of a security which confirms that duration is a good proxy for the variability of security prices (Table 6). Third, price changes of Level 1 (Level 2) securities are somewhat smaller than for Level 2 (non-HQLA) securities. Fourth, whether securities are denominated in EUR or CHF seems to play a minor role for the price variation.

Yield curves: Figure 10 and Table 4 show empirical yield curves for the different HQLA attributes in both currencies as of 7 July 2014. For both currencies the yield curves have fairly standard shapes. However, they differ with regard to their level, slope and curvature. Regardless of the currency of denomination or the duration, Level 1 securities have the lowest yields, followed by Level 2 securities. Non-HQLA securities exhibit the highest yields.

Yields and credit spreads: Figure 11 and 12 show yields of Level 1, Level 2 and non-HQLA securities in EUR and CHF for the year 2014. Both figures display generic yields for securities with a constant duration of two, three and four years respectively. ${ }^{24}$ Overall, we observe a negative trend in yields for all HQLA attributes and both currencies but the decline in yields is more pronounced for EUR-denominated securities.

The figures also reveal the HQLA spreads, which are defined as the difference between the yields of non-HQLA and Level 1 securities (Level 2 and Level 1 securities) denominated in CHF and EUR. The yield spread between EUR-denominated non-HQLA and Level 1 (Level 2 and Level 1) securities is about $45 \mathrm{bps}(15 \mathrm{bps})$. For CHF-denominated securities, the respective spreads are somewhat lower at 25 bps $(10 \mathrm{bps})$. The yield spread between non-HQLA and Level 1 securities denominated in CHF started to increase in September/October 2014 by up to $10 \mathrm{bps}$. This is at odds with the overall trend in yields for the period we examine and is an indication for the potential re-pricing due to the HQLA premium.

Summary: The descriptive analysis indicates that Level 1 securities have the highest credit quality and the highest issuance volume, followed by Level 2 and non-HQLA securities. Moreover, the analysis of the price variation suggests that it is reasonable to assign the lowest haircut to Level 1 assets, followed by Level 2 and non-HQLA assets. These differing credit and liquidity characteristics are reflected in a yield differentiation, which provides evidence for Hypothesis 1. Finally, yields of non-HQLA securities denominated in CHF increased after the regulatory change, which is not observable for their EUR counterparts.

\footnotetext{
${ }^{24}$ Generic yields with a constant duration are calculated via the daily estimation of a yield curve for Level 1 , Level 2 and non-HQLA securities in EUR and CHF using polynomic interpolation (with five degrees).
} 


\subsection{Methodology}

To exploit the impact of the regulatory change on security yields, we rely on a differencein-difference analysis. With the difference-in-difference approach, we study the impact of the regulatory change using two different groups, namely a treated group (CHF-denominated securities) and a non-treated group (EUR-denominated securities), where the non-treated group is not affected by the regulatory change and thus serves as a control group.

Since the regulatory change is only relevant for Swiss banks, which are required to fulfill their LCR requirement predominantly with CHF-denominated HQLA, a HQLA premium should be priced in for securities denominated in CHF but not for those denominated in EUR. ${ }^{25}$ As the LCR legislative principles in the EU were published on 10 October 2014, our control group should therefore be unaffected by the regulatory change in the EU up to this date. ${ }^{26}$

In order to ensure that the announcement of the ECB's covered bond purchase programme on 4 September 2014 does not bias our results by decreasing the yield of EUR-denominated covered bonds and thus the Level 2 control group which could lead to an overestimation of the HQLA premium, we exclude Level 2 securities from the baseline analysis (see Figure 6). Consequently, our empirical analysis lasts from 9 January 2014 to 9 October 2014 and contains Level 1 and non-HQLA securities, only. The period before the regulatory change covers the period from 9 January to 6 July (pre-period sample) and the period after the regulatory change lasts from 7 July until 9 October 2014 (post-period sample).

Besides the prerequisite that the regulatory change is only relevant for the treated group and leaves the control group unaffected, the other crucial assumption for the validity of our difference-in-difference analysis is that the treated and the control group behave similarly in the absence of the treatment (parallel trend assumption). Even though we can never test this assumption perfectly, the following three indicators highlight that this is the case for the treated and the control group under examination. First, the dataset is characterized by very homogenous securities denominated in CHF and EUR. Besides their similar credit and liquidity qualities, all assets considered in the analysis were SNB-eligible and hence automatically qualified as liquid assets under the former Swiss liquidity regulation. Second, the descriptive analysis suggests that the parallel trend assumption for EUR- and CHF-denominated securities is valid before the regulatory change. Figure 5 shows that HQLA spreads in EUR and CHF behaved fairly similar prior to the regulatory change, which is no longer the case afterwards. Third, several regression

\footnotetext{
${ }^{25}$ In order to take into account the potential shortage of HQLA securities denominated in CHF, the Swiss regulator has opted for the "alternative liquidity approaches" (ALA option two or three) within the Basel III LCR framework. Option two allows banks with adequate foreign exchange management to cover a fraction of NCOF with HQLA denominated in pre-defined foreign currencies. The impact of the regulatory change on yields of EUR-denominated HQLA securities should, however, be negligible, since the volume of EUR-denominated HQLA securities is large compared to the volume of NCOF of Swiss banks that can potentially be covered by HQLA denominated in EUR.

${ }^{26}$ Note that if the regulatory change was partially anticipated, this would lead to an underestimation of the HQLA premium and we discuss this in more detail, below.
} 
analyses for time periods without regulatory treatment (hereinafter "placebo regression") with fictional regulatory changes in the pre-period sample fail to reject the parallel trend assumption (see detailed discussion in the subsection Robustness). ${ }^{27}$ Overall, this quasi-natural experiment fulfils the crucial difference-in-difference assumption that, disregarding the treatment, the HQLA spreads in the treated and the non-treated groups behaved very similar.

\footnotetext{
${ }^{27}$ Among other things, we believe that the closeness of the HQLA spreads can, at least in part, be attributed to the highly integrated nature of the economies in question and to the minimum exchange rate that has been in place throughout 2014 .
} 
Figure 5: Parallel trend assumption
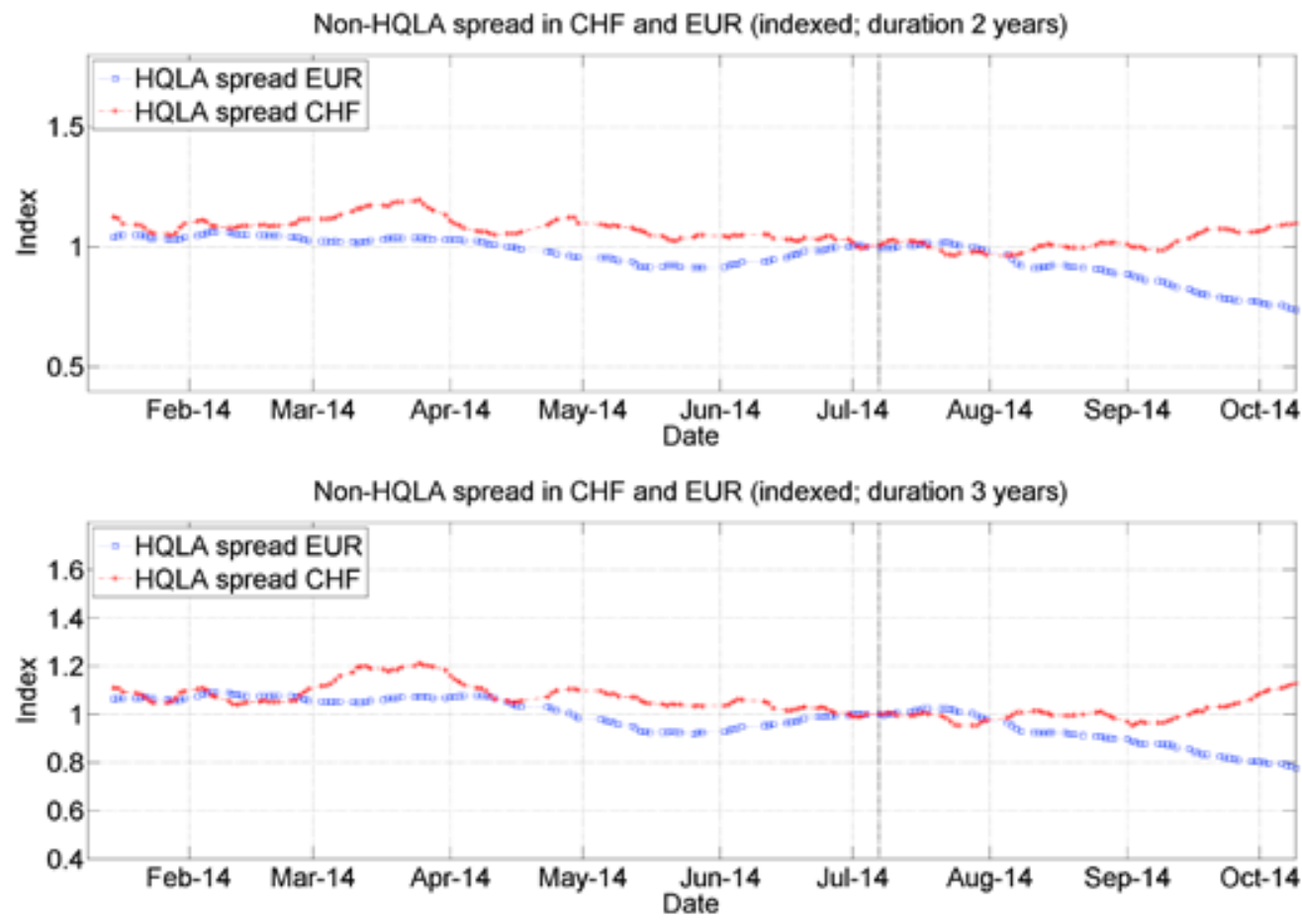

Non-HQLA spread in CHF and EUR (indexed; duration 4 years)

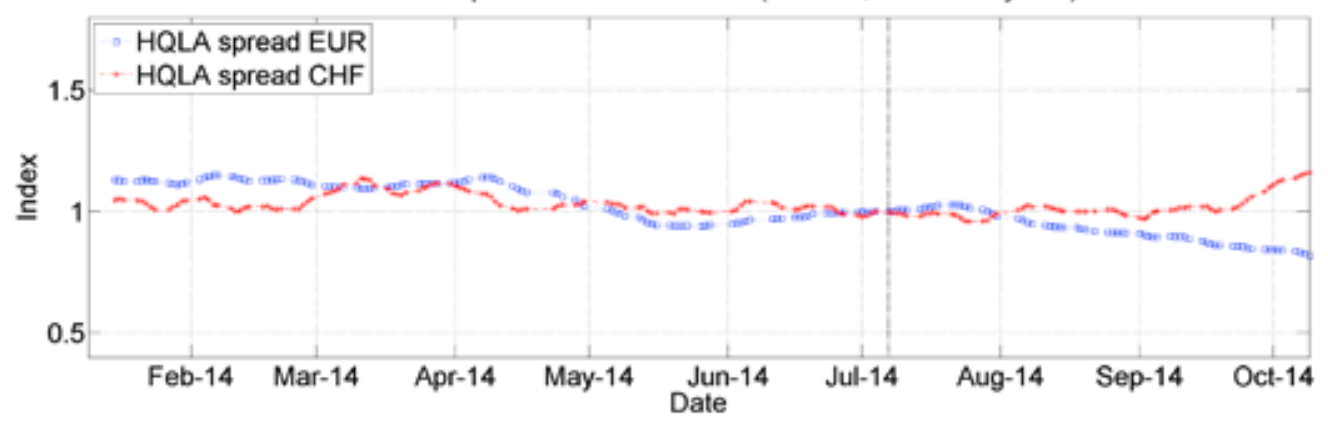

Figure 5 shows generic HQLA spreads (indexed rolling one-week moving averages) for securities denominated in EUR and CHF with a constant duration of two, three and four years. EUR HQLA spreads are calculated as non-HQLA $A_{E U R}$-Level $1_{E U R}$. CHF HQLA spreads are calculated as non-HQLA ${ }_{C H F}-$ Level $1_{C H F}$. The HQLA spread in EUR is represented by blue squares. The HQLA spread in CHF is depicted by red crosses. HQLA spreads are indexed to one on the day before the regulatory treatment (6 July 2014). The vertical lines represent the announcement days of the regulatory change in Switzerland (7 July 2014) and in the European Union (10 October 2014). Generic yields with a constant duration are calculated via the daily estimation of a yield curve for Level 1, Level 2 and non-HQLA securities denominated in EUR and CHF using polynomic interpolation (with five degrees). 


\subsection{Econometric specification}

For the difference-in-difference analysis we follow the recommendations by Bertrand, Duflo and Mullainathan (2004) as well as Degryse, Kim and Ongena (2009) and proceed as follows: First, the dataset is divided into two sub-periods, namely a period before and a period after the regulatory change. The pre-period sample runs from 9 January 2014 to 6 July 2014 and the post-period sample from 7 July 2014 to 9 October 2014. Second, we calculate average yields of each individual security $i$ for the pre- and post-period samples $\left(\bar{y}_{i}^{\text {Pre }}, \bar{y}_{i}^{\text {Post }}\right)$. Third, the change between the two average yields $\left(\left(\bar{y}^{\text {Post }}-\bar{y}^{\text {Pre }}\right)_{i}\right)$ is calculated for each individual security. Fourth, we run a regression of the individual yield changes on a constant and a dummy variable for nonHQLA securities (non-HQLA ${ }_{i}$ ), while controlling for the currency of denomination by using a dummy variable for all securities denominated in $\mathrm{CHF}\left(\mathrm{CHF}_{i}\right)$. Additionally, we include an interaction term for non-HQLA securities denominated in CHF (non-HQLA ${ }_{i}^{C H F}$ ) which represents the HQLA premium and thus the variable of interest. Finally, as securities with different durations are included in the regression, we control for the term structure of interest rates using the securities' duration. As the EUR and CHF term structure of interest rates are not identical (see Figure 10), we control for the non-linear term structure of the two currencies individually by including the securities' duration $\left(\right.$ duration $_{i}^{C H F}$, duration ${ }_{i}^{E U R}$ ) and the securities' squared duration (duration ${ }_{i}^{2 C H F}$, duration ${ }_{i}^{2 E U R}$ ) as of 7 July 2014. ${ }^{28}$ Table 7 exemplifies the use of dummy variables in the regression specification.

Table 1: Dummy variables in regression analysis

\begin{tabular}{lcccc}
\hline \hline & \multicolumn{2}{c}{ Level 1 } & \multicolumn{2}{c}{ non-HQLA } \\
Dummy variables & EUR & CHF & EUR & CHF \\
\hline non-HQLA & & & 1 & 1 \\
CHF & & 1 & & 1 \\
CHF x non-HQLA & & & & 1 \\
const. & 1 & 1 & 1 & 1 \\
\hline
\end{tabular}

Table 7 exemplifies the use of dummy variables (rows) in the regression specification, given the securities' HQLA attributes as well as the currency of denomination (columns).

In this regression specification, which eliminates the time series dimension of the dataset by calculating average yields for each security pre and post the regulatory treatment, the regression standard errors do not suffer from a potential serial autocorrelation problem as documented by Bertrand et al. (2004). ${ }^{29}$ More formally, we can write the OLS regression model as outlined in Equation 3.

\footnotetext{
${ }^{28}$ Note that the regression results are quantitatively unaffected when using different specifications to control for the term structure of interest rates or the duration date (see Table 9).

${ }^{29}$ Among others, the advantage of such a methodology is described by Degryse et al. (2009) and applied by Cerqueiro, Ongena and Roszbach (2016).
} 


$$
\begin{array}{r}
\left(\bar{y}^{\text {Post }}-\bar{y}^{\text {Pre }}\right)_{i}=\alpha+\beta_{1} \text { non-HQLA }_{i}+\beta_{2} \mathrm{CHF}_{i} \\
+\beta_{3} \text { CHF x non-HQLA }+\beta_{4} \text { duration }_{i}^{C H F} \\
+\beta_{5} \text { duration }_{i}^{2 C H F}+\beta_{6} \text { duration }_{i}^{E U R}+\beta_{7} \text { duration }_{i}^{2 E U R}+\epsilon_{i} .
\end{array}
$$

The general development of yields is captured by the constant. Since we control for the addon of non-HQLA securities as well as the currency of denomination, the constant represents the development of EUR-denominated Level 1 yields. By controlling for the add-on of non-HQLA securities denominated in CHF, the $C H F_{i}$ coefficient represents the development of CHF Level 1 yields vis-à-vis EUR Level 1 yields. Moreover, since Level 1 securities denominated in CHF are not affected by the regulatory change (i.e. their regulatory treatment remains unchanged), the $C H F_{i}$ coefficient captures only yield changes that affect all securities denominated in CHF equally (i.e. a general change in CHF yields). Consequently, the impact of the regulatory change and hence the HQLA premium is captured by the coefficient of the CHF non-HQLA dummy variable, which we expect to be positive and statistically significant.

\subsection{Results}

The regression results of our baseline analysis are displayed in Table 2, Column (1). The regression coefficient for non-HQLA securities denominated in CHF (non-HQLA ${ }^{\mathrm{CHF}}$ ) is around 0.04 and is significantly different from zero. Thus, yields of CHF securities which are subject to a regulatory downgrade increased by 4 bps relative to the corresponding EUR non-HQLA securities. The coefficient has the expected positive sign and is of statistical significance. However, with $4 \mathrm{bps}$, the magnitude of the HQLA premium is rather small.

The negative trend in EUR Level 1 yields is reflected by the negative coefficient of the constant. The yield decrease for EUR non-HQLA securities is more pronounced than for EUR Level 1 assets, as is indicated by the negative and statistically significant coefficient. The coefficient of the dummy variable for securities denominated in CHF is positive and statistically significant. This implies that the average yield decrease of CHF-denominated Level 1 securities is less pronounced than the average yield decrease of EUR-denominated Level 1 securities. Finally, the slope $\left(\right.$ duration $\left._{i}\right)$ and the curvature coefficients $\left(\right.$ duration $\left._{i}^{2}\right)$ are statistically significant for both currencies (see Table 9, Column (1)). Overall, the model fit is relatively good with an adjusted $\mathrm{R}^{2}$ of $0.86 .^{30}$

\footnotetext{
${ }^{30}$ This is mainly due to the inclusion of the securities' duration, which explains a significant part of the variation of yield changes. Note that without considering the securities' residual maturities, the adjusted $\mathrm{R}^{2}$ is 0.28 .
} 
Table 2: Difference-in-difference regression results (coefficient are in percentage points)

\begin{tabular}{lcccccc}
\hline \hline & $(1)$ & $(2)$ & $(3)$ & $(4)$ & $(5)$ & $(6)$ \\
& Baseline & Liquidity & CH-issuer & LiqV & Placebo & Level 2 \\
\hline CHF x non-HQLA & $0.0387^{* *}$ & $0.0436^{* * *}$ & $0.0446^{* *}$ & $0.0342^{* *}$ & 0.00527 & 0.0130 \\
& $(2.53)$ & $(2.83)$ & $(2.53)$ & $(2.22)$ & $(0.66)$ & $(0.90)$ \\
non-HQLA & $-0.0576^{* * *}$ & $-0.0576^{* * *}$ & $-0.0576^{* * *}$ & $-0.0559^{* * *}$ & 0.00372 & $-0.0338^{* * *}$ \\
& $(-4.52)$ & $(-4.51)$ & $(-4.51)$ & $(-4.38)$ & $(0.95)$ & $(-2.92)$ \\
CHF & $0.150^{* * *}$ & $0.155^{* * *}$ & $0.183^{* * *}$ & $0.159^{* * *}$ & $0.0167^{*}$ & $0.0902^{* * *}$ \\
& $(9.31)$ & $(9.86)$ & $(7.51)$ & $(9.71)$ & $(1.84)$ & $(8.18)$ \\
CHF x Level 2 & & & & & $0.0167^{* *}$ \\
& & & & & $(2.07)$ \\
Level 2 & & & & & $-0.0307^{* * *}$ \\
& & & & & $(-7.19)$ \\
Constant & $-0.0678^{* * *}$ & $-0.0678^{* * *}$ & $-0.0678^{* * *}$ & $-0.0739^{* * *}$ & $-0.0444^{* * *}$ & $-0.0220^{* * *}$ \\
& $(-5.89)$ & $(-5.88)$ & $(-5.87)$ & $(-6.29)$ & $(-11.14)$ & $(-3.27)$ \\
\hline Observations & 822 & 735 & 589 & 822 & 822 & 1660 \\
Adjusted $R^{2}$ & 0.857 & 0.884 & 0.858 & 0.852 & 0.471 & 0.863 \\
Duration $(\mathrm{CHF} /$ EUR) & Yes & Yes & Yes & Yes & Yes & Yes \\
Duration & & & & & & Yes \\
\hline \hline
\end{tabular}

$t$ statistics in parentheses

${ }^{*} p<0.10,{ }^{* *} p<0.05,{ }^{* * *} p<0.01$

Table 2 shows the baseline regression results (Column (1)) and the robustness checks (Columns (2) - (6)) for the difference-in-difference analysis. Coefficients are expressed in percentage points. The dependent variable is the absolute yield change between the average yield post and pre $\left(\left(\bar{y}^{\text {Post }}-\bar{y}^{\text {Pre }}\right)_{i}\right)$ the regulatory change $(7$ July 2014) for each individual security $(i)$. The regression specification is given in Equation (3). The pre-period sample runs from 9 January to 6 July 2014. The post-period sample lasts from 7 July to 9 October 2014. Column (2) shows the regression results when using only securities with an outstanding volume of at least CHF $175 \mathrm{mn}$. Column (3) shows the regression results when omitting CHF securities issued by foreign issuers. Column (4) shows the regression results when using the publication of the legislative principles as the regulatory change. Column (5) shows the results of the placebo regression when using a fictional regulatory change during the pre-period sample (between 9 January and 6 March 2014, fictional regulatory change 5 February 2014). Column (6) shows the regression results using a post-period sample which runs only until one day before the announcement of the ECB covered bond purchase program (announced on 4 September 2014) using Level 1, Level 2 and non-HQLA securities. Regression coefficients for the securities' duration are not displayed (see Table 9 for more details). Huber-White corrected standard errors are used. ${ }^{* * *},{ }^{* *}$ and $*$ denote statistical significance (two-tailed) at the $1 \%, 5 \%$, and $10 \%$ significance level, respectively. t-statistics are in parentheses below the coefficients. 


\subsection{Robustness}

Below, we discuss several robustness checks with respect to both the specification of our model and to the data sampling. Overall, we find that the results from the baseline regression are confirmed.

Outstanding volume: In Table 2, Column (2), we assess whether our findings depend on securities with a relatively small outstanding volume. To do so, we only consider CHF securities with an outstanding volume of more than CHF $175 \mathrm{mn}$. This is, we exclude the least liquid $25 \%$ of all CHF denominated securities from the dataset (i.e. 87 securities). ${ }^{31}$ In this regression specification, the coefficient for non-HQLA securities denominated in CHF is about 4.5 bps which suggests that the HQLA premium may be slightly larger for more liquid securities.

Swiss issuers: Table 2, Column (3) shows the baseline regression specification, using only CHF-denominated securities of Swiss issuers in the treatment group. The intuition behind this regression specification is that the HQLA premium might be more pronounced for domestic securities due to a potential home bias. Also with this regression specification, the HQLA premium is about 4.5 bps and thus slightly larger than in the baseline regression.

Regulatory change: In order to test the robustness of our regression specification, we repeat the regression analysis using the announcement of the LCR by the Swiss Federal Council as the date of the regulatory change. When using the 25 June 2014 instead of the 7 July 2014 as the treatment date, our results remain broadly unchanged (see Table 2, Column (4)).

Placebo regression: In order to test the validity of the difference-in-difference approach, we repeat the regression analysis for a period without regulatory treatment. ${ }^{32}$ In the absence of the regulatory treatment, we expect the treatment coefficients to be close to zero and statistically insignificant, confirming that, in absence of the treatment, the control group and the treatment group are indeed very similar. Table 2, Column (5) reports the results of the placebo regression when using the observation period 9 January to 6 March 2014, with a fictional date for the regulatory change on 5 February 2014. The treatment group and the control group are indeed very similar, as the non-HQLA coefficient for securities in CHF (non-HQLA ${ }^{C H F}$ ) is close to zero and statistically insignificant. The development of non-HQLA securities denominated in CHF is therefore well captured by the general non-HQLA $i$ dummy.

Shorter post-period sample: In our baseline regression, we end our post-period sample on 9

\footnotetext{
${ }^{31}$ Of the excluded 87 securities, there are 55 Level 1 and 32 non-HQLA securities.

${ }^{32}$ Note that we have tested several placebo regression specifications which all fail to reject the parallel trend assumption. For simplicity, we just display one possible regression specification.
} 
October 2014, but exclude Level 2 securities to ensure that our control group is unaffected by the announcement of the ECB covered bond purchase programme on 4 September 2014. Table 2, Column (6) shows the regression results using a post-period sample ending on 3 September 2014. This allows us to run a regression analysis which also includes Level 2 securities (see Table 7 for the specification of the dummy variables). With this regression specification, the HQLA premium for Level 2 and non-HQLA securities is about 1.5 bps. The coefficient for Level 2 securities denominated in CHF is statistically significant, whereas the coefficient for non-HQLA securities is not. In our view, the smaller HQLA premium for non-HQLA securities compared to our baseline regression is due to the fact that banks did not adjust their portfolios immediately after the regulatory change but rather gradually over time which is confirmed by anecdotal evidence from market participants.

Term structure specification: In order to test whether our results depend on the term structure specification, the choice of the securities' duration date or whether we control for the securities duration or the residual maturity, several alternative term structure specifications have been tested. Table 9 reports the corresponding regression results as well as our baseline results (illustrated in Column (1)). Overall, we find no qualitative discrepancies from our baseline results irrespective of the specification chosen. Column (2) reports the results when using the securities' residual maturity instead of its duration. Column (3) displays the regression results when using the securities' residual maturity as well as the coupon. Columns (4) and (5) use the information on the securities' duration as of 9 May respectively 10 October 2014 instead of 7 July 2014. Finally, Column (6) reports the regression results when including a cubic term to control for the term structure into our baseline regression model.

HQLA spreads: In order to test whether our findings are robust irrespective of the econometric approach chosen, we repeat our analysis and use daily HQLA spreads between non-HQLA and Level 1 securities denominated in CHF and EUR $\left(\right.$ spread $\left._{j, t}\right)$ with identical generic durations $(j)$ ranging from one to ten years (see also Figure 5). These spreads are regressed on a CHF dummy $\left(\mathrm{CHF}_{j, t}\right)$, a post-period sample dummy (Post $\left.{ }_{j, t}\right)$ as well as the corresponding interaction dummy $\left(\right.$ Post $\left.\mathrm{x} \mathrm{CHF}_{j, t}\right)$, i.e. a dummy variable for $\mathrm{CHF}$ securities after the regulatory treatment, which represents the HQLA premium and is thus the variable of interest. More formally, we can write the OLS regression model as outlined in Equation 4.

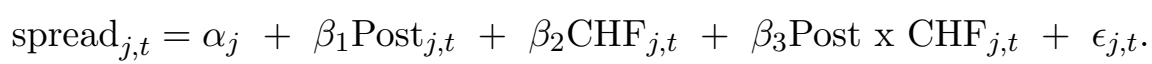

The regression results reported in Table 8 show again a positive and statistically significant 
HQLA premium which is in the order of 6 bps and thus comparable to our baseline results. ${ }^{33}$

HQLA spreads in CHF: Another econometric approach is to focus on securities denominated in CHF, only. This approach does therefore not rely on EUR denominated securities serving as a control group. To do so, we regress HQLA spreads between non-HQLA and Level 1 securities denominated in CHF with generic durations of one to ten years (see Figure 12) on a post-period sample dummy which represents the HQLA premium and is thus the variable of interest as well as the CBOE Volatility Index (VIX) which is expected to approximate yield spreads and thus is a proxy for our control group. Table 10 shows the corresponding regression results. Again, we find a positive and statistically significant HQLA premium in the order of about 2 bps. Therefore, also the analysis relying on CHF denominated securities only provides evidence for a small but positive and statistically significant HQLA premium.

\section{Discussion of results}

The empirical results provide evidence for the existence of a HQLA premium of a rather small magnitude. This is in line with Hypothesis 3 of the theoretical considerations when taking into account the current monetary policy environment in Switzerland. Subsequently, we discuss our empirical findings in more detail.

Monetary policy environment: As a result of the unconventional measures taken by the SNB since 2008, and in particular due to foreign currency purchases since 2009, the banking system currently holds large excess reserves and CHF interest rates are close to the rate the SNB pays on reserves (until 2015, the interest rate on reserves was $0 \%$ ). At the end of 2015, the reserve holdings of banks were approximately 95 times as high as they were before the financial crisis. In contrast to the kind of quantitative easing that creates reserves by purchasing HQLA securities in a given central bank's domestic currency (thereby leaving the stock of HQLA unchanged), the SNB has created reserves by purchasing foreign assets. In doing so, the SNB has considerably increased the stock of Level 1 securities denominated in CHF. ${ }^{34}$ The theoretical considerations of Hypothesis 3 suggest that in such a monetary policy environment, the HQLA premium is expected be small or close to zero. This corresponds to the findings in our empirical analysis.

\footnotetext{
${ }^{33}$ Note that we have also conducted a regression analysis using daily security yields with dummy variables specified as outline in our baseline regression, however, interacted with a post-period sample dummy and using time and ISIN fixed effects. Using such a methodology, which is for instance applied by Lambert, Noth and Schwer (2015), yields again to a positive and statistically significant HQLA premium.

${ }^{34}$ As a mirror image of the additional reserve holdings by banks, the foreign currency purchases have also created additional liabilities. An analysis of the consolidated balance sheet of the banking system shows that it is primarily retail and wholesale deposits that have increased in response to the foreign currency purchases of the SNB. As the outflow parameters that are assigned to those liabilities are rather small, foreign currency purchases have increased the banking system's LCR.
} 
Alternative Liquidity Approaches (ALA): The crucial question that arises from these considerations is whether, and to what extent, the HQLA premium would increase under normal monetary policy conditions. In Switzerland, the regulator has stated that there is a structural shortage of HQLA securities denominated in CHF given the HQLA needs of the banking system. This is due to the small capital market and in particular the low volume of government debt outstanding. In the absence of any additional mitigating factors, we would expect to encounter an economically significant HQLA premium under pre-crisis monetary policy conditions (see Hypothesis 2).

The BCBS acknowledges that there are jurisdictions with a structural shortage of HQLA, and for these jurisdictions, the BCBS allows for the application of so-called ALA options. There are three different ALA options and all three are intended to widen the set of securities that count towards HQLA (see Basel Committee on Banking Supervision (2013) for a detailed description of the ALA options). In view of the structural shortage of HQLA securities denominated in CHF, the regulator in Switzerland permits Swiss banks to apply an ALA option in order to fulfill the LCR. Swiss banks may apply either ALA option two or three. Option two allows banks with an adequate foreign exchange management to cover a fraction of NCOF denominated in CHF with HQLA denominated in pre-defined foreign currencies. Option three relaxes the $40 \%$ Level 2 securities cap. Theoretically, both ALA options should reduce the HQLA premium by increasing the supply of HQLA securities (a rightward shift of the HQLA supply curve in our theoretical model).

Methodology: In the econometric specification used, the exogeneity of the announcement of the regulatory change and the validity of the control group are key. In this respect, our empirical analysis underestimates the HQLA premium if market participants did not price in the HQLA premium immediately after the regulatory change, but rather gradually over time. Moreover, we would also underestimate the HQLA premium if the regulatory change was anticipated (the first draft of the Basel III LCR rulebook was published in 2010 (Basel Committee on Banking Supervision, 2010)). This may have led banks to anticipate the regulatory change to some extent, which in turn may have caused a re-adjustment of banks' securities portfolios and a re-pricing of securities prior to the regulatory change. This violation of the exogeneity assumption would lead to an underestimation of the HQLA premium. The same is true if securities in the euro area had been re-priced in anticipation of the regulatory change. 


\section{$7 \quad$ Policy implications}

In the following, we discuss potential policy implications of our findings which are relevant for central banks, market participants and regulators in general.

Monetary policy: A non-zero HQLA premium affects the equilibrium relationship between asset prices and central bank policy rates (see Bech and Keister (2014) as well as BIS Committee on the Global Financial System (2015)). Thus, central banks may need to take the HQLA premium into account and target a different level for their policy rates in order to establish the monetary conditions that prevailed before the regulatory change. If the HQLA premium is also a function of the availability of HQLA, establishing the same monetary conditions will require adjustments of the policy rate in response to changes of the HQLA premium. Moreover, if there is a scarcity of HQLA securities, banks' demand for reserves will increase in order to ensure compliance with the LCR. This, in turn, implies that central banks will be forced to operate with larger balance sheets than they would without the LCR (see Debelle (2011)). Finally, the choice of how to exit unconventional monetary policy might be affected by a potential scarcity of HQLA and a non-zero HQLA premium (see Berentsen et al. (2015)).

Bond markets: A non-zero HQLA premium suggests that conditions on the primary bond market change in response to the introduction of the LCR. Specifically, funding costs for issuers of non-HQLA securities increase relative to funding costs for issuers of Level 1 securities. Our findings thus highlight that the LCR may promote the issuance of government debt compared to private debt and thus incentivize the production of such securities. This in turn decreases again the HQLA premium as a second round effect. Ultimately, this implies a re-allocation of resources in the real economy (see, for example, Nyborg (2015a)) which may be attributed to the change in regulatory requirements.

Collateral frameworks: The price differentiation of HQLA and non-HQLA securities has implications for collateral frameworks of central banks too. On the one hand, if central banks accept both HQLA and non-HQLA securities in their collateral framework, banks may increasingly come to rely on central bank funding against non-HQLA securities (cheapest-to-deliver; see, for example, Nyborg (2015b), Nyborg (2015a), and Fecht et al. (2015)). ${ }^{35}$ On the other hand, if central banks align their collateral policy and only accept HQLA collateral, they may reinforce the HQLA premium. The SNB is an example for a central bank that has responded to the LCR by aligning its collateral framework with the definition of HQLA. This trade-off also applies for interbank repo markets.

\footnotetext{
${ }^{35}$ Increasing central bank haircuts for non-HQLA securities may be one way to reduce this incentive.
} 


\section{Conclusion}

The Basel III LCR requires banks to hold an adequate stock of HQLA relative to their expected NCOF in order to withstand severe short-term liquidity shocks. In this paper we examine whether the HQLA classification of a security affects its market price. We quantify this change empirically and, as suggested by Stein (2013), call it HQLA premium.

In our empirical analysis, we show that there has been a yield differentiation between Level 1 , Level 2 and non-HQLA securities before the regulatory change and we find that the LCR has reinforced this yield differentiation by adding an HQLA premium in the order of 4 bps. Guided by theoretical considerations, we claim that our estimate represents a lower bound of the HQLA premium. This is primarily due to ample supply of HQLA in the form of reserves resulting from the SNB's unconventional monetary policy measures and the fact that market interest rates are close to the interest rate paid on reserves.

The findings of this paper have various policy implications. First, in the event of a non-zero HQLA premium, several challenges arise for monetary policy implementation, as central banks may need to target a different level for their policy rate in order to take into account the HQLA premium and thus establish the same monetary conditions as before the regulatory change. Second, central banks may be forced to operate with larger balance sheets due to additional demand for reserves associated with banks' efforts to fulfill their LCR. This might also affect the choice of policy instruments central banks deploy to exit the current unconventional monetary policy. Third, in the event of a non-zero HQLA premium, issuing non-HQLA or Level 2 securities has become more expensive relative to Level 1 securities and thus incentivizes the production of Level 1 assets (primarily government debt). Fourth, central banks may need to adjust their collateral policy in response to the LCR in order to prevent banks from relying increasingly heavily on central bank funding against non-HQLA securities.

Our analysis is intended to contribute to a broader understanding of the LCR. Given the importance of the LCR for banks and the potentially far-reaching implications for the increasingly interconnected global financial system, further empirical research in this area is essential. Moreover, the methodology we have used to estimate the HQLA premium may also be applied to assess the HQLA premium in other currency areas. 


\section{References}

Amihud, Yakov \& Haim Mendelson (1986) "Asset pricing and the bid-ask spread", Journal of Financial Economics, 17 (2), pp. 223-249.

Arslanalp, Serkan \& Takahiro Tsuda (2014) "Tracking global demand for advanced economy sovereign debt", IMF Economic Review, 62 (3), pp. 430-464.

Ashcraft, Adam, Nicolae Garleanu \& Lasse Heje Pedersen (2010) "Two monetary tools: Interest rates and haircuts", NBER Macroeconomics Annual 2010, 25, pp. 143-180.

Banerjee, Ryan \& Hitoshi Mio (2014) "The impact of liquidity regulation on banks", BIS Working Papers, No 470.

Bartolini, Leonardo, Spence Hilton, Suresh Sundaresan \& Christopher Tonetti (2010) "Collateral values by asset class: Evidence from primary securities dealers", Review of Financial Studies, 24 (1), pp. 248-278.

Basel Committee on Banking Supervision (1988) "International convergence of capital measurement and capital standards".

Basel Committee on Banking Supervision (2010) "Basel III: International framework for liquidity risk measurement, standards and monitoring".

Basel Committee on Banking Supervision (2013) "Basel III: The Liquidity Coverage Ratio and liquidity risk monitoring tools".

Bech, Morten \& Todd Keister (2014) "On the economics of committed liquidity facilities", BIS Working Paper, No 439.

Berentsen, Aleksander, Sebastien Kraenzlin \& Benjamin Müller (2015) "Exit strategies and trade dynamics in repo markets", SNB Working Paper, No 9.

Bertrand, Marianne, Esther Duflo \& Sendhil Mullainathan (2004) "How much should we trust differences-in-differences estimates?", The Quarterly Journal of Economics, 119 (1), pp. 249-275.

Bindseil, Ulrich \& Francesco Papadia (2006) "Credit risk mitigation in central bank operations and its effects on financial markets: the case of the eurosystem", ECB Occasional Paper, No 49.

BIS Committee on the Global Financial System (2015) "Regulatory change and monetary policy", CGFS Papers, No 54. 
Bonner, Clemens (2012) "Liquidity regulation, funding costs and corporate lending", De Nederlandsche Bank Working Paper, No 361.

Bonner, Clemens \& Sylvester CW Eijffinger (2012) "The impact of the LCR on the interbank money market", CEPR Discussion Paper, No 9142.

Buiter, Willem H. \& Anne C. Sibert (2005) "How the eurosystem's treatment of collateral in its open market operations weakens fiscal discipline in the eurozone (and what to do about it)", CEPR Discussion Papers, No 5387.

Carlson, Mark A, Burcu Duygan-Bump, Fabio Massimo Natalucci, William R Nelson, Marcelo Ochoa, Jeremy C Stein \& Skander Van den Heuvel (2014) "The demand for short-term, safe assets and financial stability: Some evidence and implications for central bank policies", FEDS Working Paper, No 102.

Cerqueiro, Geraldo, Steven Ongena \& Kasper Roszbach (2016) "Collateralization, bank loan rates and monitoring", The Journal of Finance, 71 (3), pp. 1295-1322.

Chapman, James, Jonathan Chiu \& Miguel Molico (2011) "Central bank haircut policy", Annals of Finance, 7 (3), pp. 319-348.

Debelle, Guy (2011) "The committed liquidity facility", Speech at the "APRA (Australian Prudential Regulation Authority) Basel III Implementation Workshop 2011", Sydney.

Degryse, Hans, Moshe Kim \& Steven Ongena (2009) Microeconometrics of banking: methods, applications, and results, Oxford University Press.

Fecht, Falko, Kjell Nyborg, Jorg Rocholl \& Jiri Woschitz (2015) "Collateral, central bank repos, and systemic arbitrage", Working Paper, University of Zurich and Swiss Finance Institute, forthcoming.

Federal Council (2003) "Verordnung über die Banken und Sparkassen".

Federal Council (2014) "Revision of Liquidity Ordinance for banks".

Fender, Ingo \& Ulf Lewrick (2013) "Mind the gap? Sources and implications of supplydemand imbalances in collateral asset markets", BIS Quarterly Review, September 2013.

FINMA (2014) "Finma publishes fully revised circular: Liquidity risks - banks".

Fuhrer, Lucas Marc, Basil Guggenheim \& Silvio Schumacher (2016) "Re-use of collateral in the repo market", Journal of Money, Credit and Banking, 48 (6), pp. 1169-1193.

Greene, William H. (2003) Econometric Analysis, Upper Saddle River, NJ, Prentice Hall, 5th edition. 
Kiyotaki, Nobuhiro \& John Moore (2005) "Liquidity and asset prices", International Economic Review, 46 (2), pp. 317-349.

Krishnamurthy, Arvind \& Annette Vissing-Jorgensen (2012) "The aggregate demand for treasury debt", Journal of Political Economy, 120 (2), pp. 233-267.

Lagos, Ricardo (2010) "Asset prices and liquidity in an exchange economy", Journal of Monetary Economics, 57 (8), pp. 913-930.

Lagos, Ricardo \& Guillaume Rocheteau (2009) "Liquidity in Asset Markets With Search Frictions", Econometrica, 77 (2), pp. 403-426.

Lagos, Ricardo \& Randall Wright (2005) "A Unified Framework for Monetary Theory and Policy Analysis", Journal of Political Economy, 113 (3), pp. 463-484.

Lambert, Claudia, Felix Noth \& Ulrich Schwer (2015) "How do insured deposits affect bank risk? Evidence from the 2008 Emergency Economic Stabilization Act", Journal of Financial Intermediation, forthcoming.

Nagel, Stefan (2016) "The liquidity premium of near-money assets", The Quarterly Journal of Economics, forthcoming.

Nixon, Kevin, Richard Portes \& Jean-Pierre Danthine (2013) "Policy panel", Alexandra Heath, Matthew Lilley \& Mark Manning eds. Liquidity and Funding Markets, Reserve Bank of Australia Annual Conference Volume 2013.

Nyborg, Kjell G (2015a) "Central bank collateral frameworks", Swiss Finance Institute Research Paper, No 10.

Nyborg, Kjell G (2015b) The Open Secret of Central Banks, Cambridge University Press, forthcoming.

Nyborg, Kjell G \& Per Östberg (2014) "Money and liquidity in financial markets", Journal of Financial Economics, 112 (1), pp. 30-52.

Rocheteau, Guillaume, Randall Wright \& Sylvia Xiaolin Xiao (2015) "Open market operations", mimeo.

Stein, Jeremy C (2013) "Liquidity regulation and central banking", Speech at the "Finding the Right Balance" 2013 Credit Markets Symposium sponsored by the Federal Reserve Bank of Richmond, Charlotte, North Carolina.

Swiss National Bank (2014) "Swiss National Bank aligns collateral policy with new liquidity provisions". 
Swiss National Bank (2015) "Instruction sheet on collateral eligible for SNB repos".

Williamson, Stephen D. (2012) "Liquidity, monetary policy, and the financial crisis: A new monetarist approach", American Economic Review, 102 (6), pp. 2570-2605. 


\section{A Appendix}

Figure 6: Timeline of key events

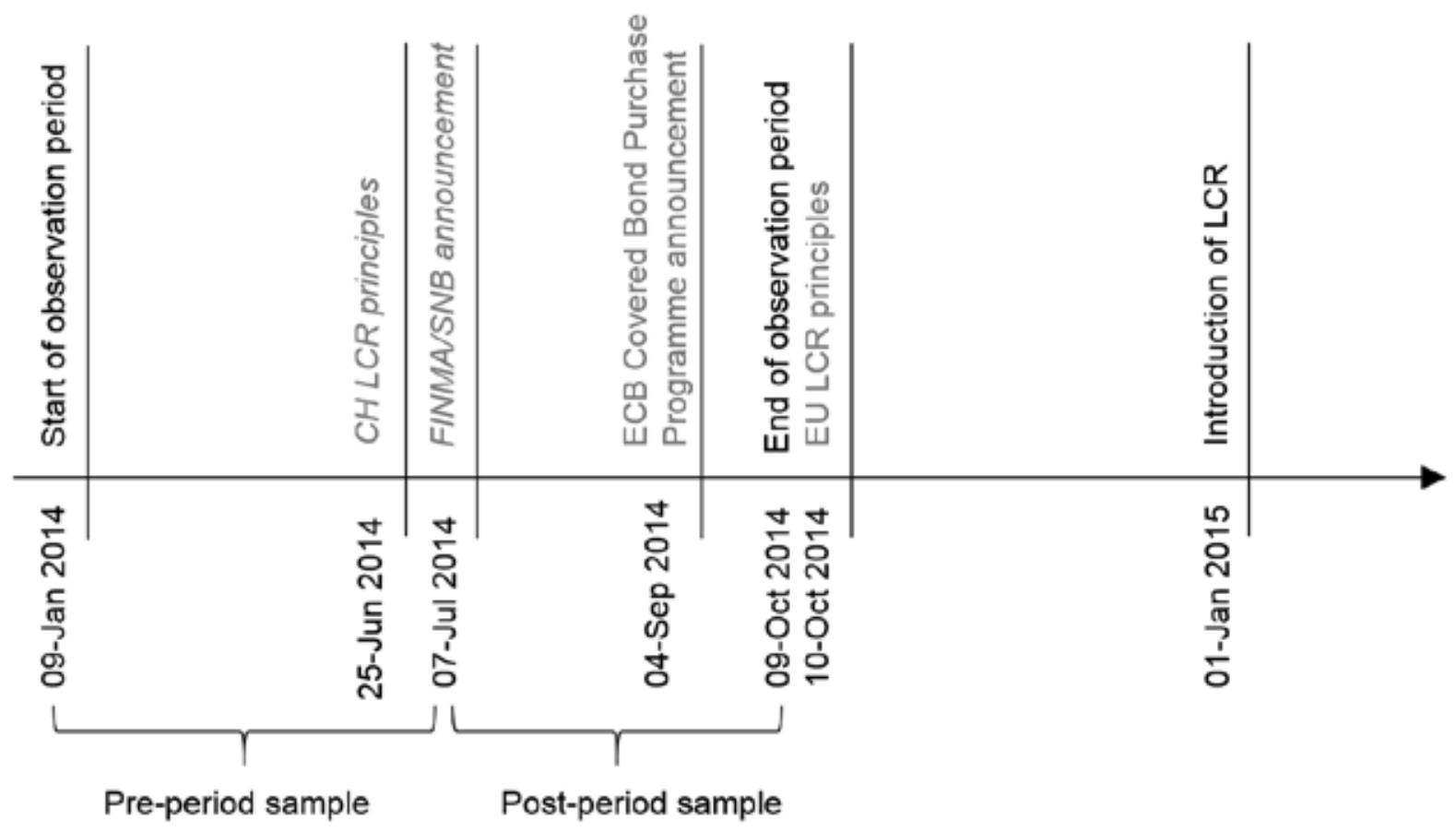

Figure 6 shows the timeline of key events. General events are depicted in black, Switzerland-specific events in gray and italics, and EU-specific events in gray and regular font. These events define the pre- and post-period samples of the empirical analysis. 
Figure 7: Credit ratings of securities denominated in CHF

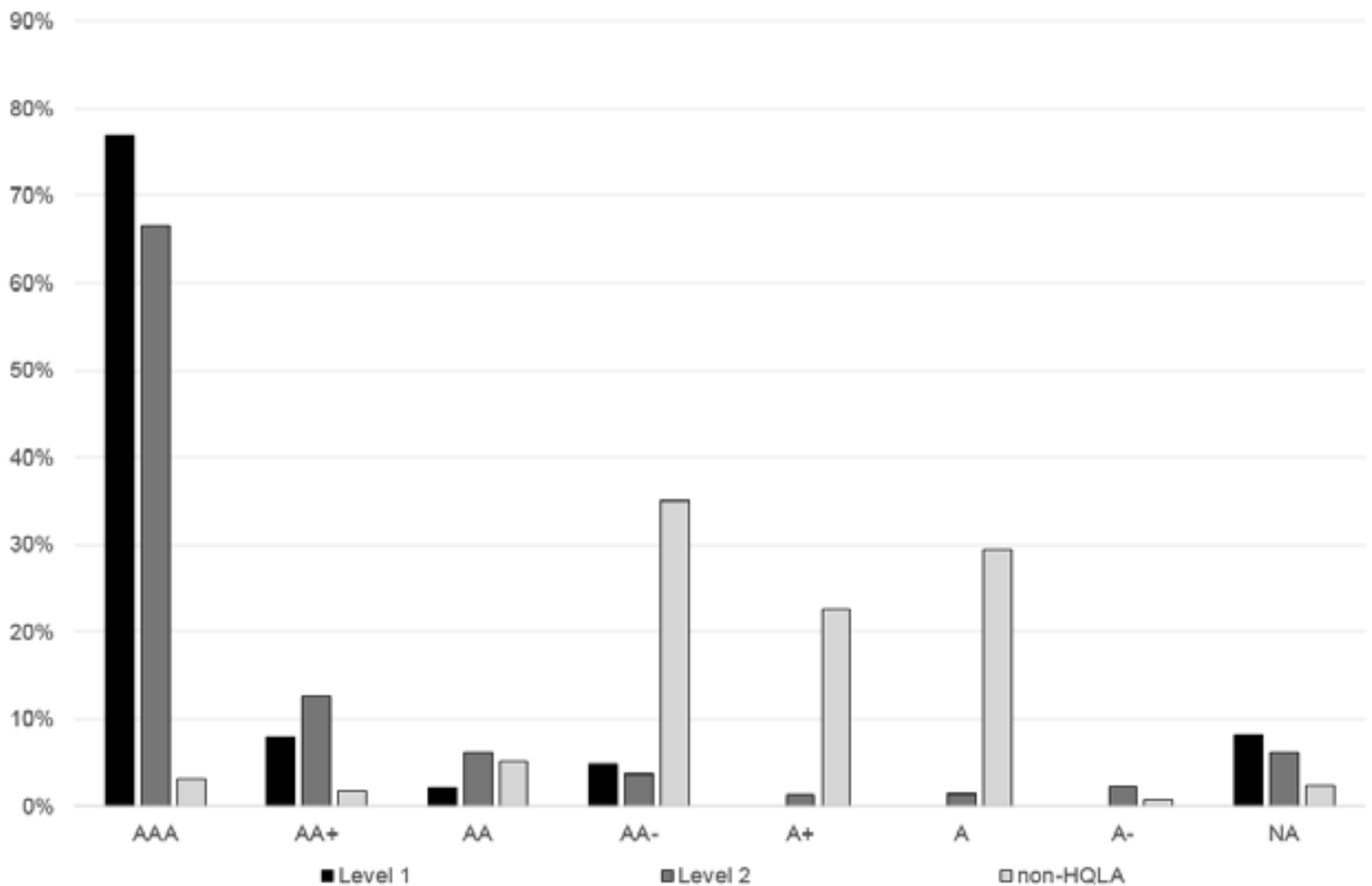

Figure 7 shows the volume-weighted share of securities by credit rating for Level 1, Level 2 and non-HQLA securities denominated in CHF. The black bars show Level 1 securities, the dark gray bars represent Level 2 securities, and the light gray bars show non-HQLA securities. The second-best rating from Moody's, S\&P and Fitch as of 7 July 2014 is used for each security (note that if there is only one rating available, this rating is used). 
Figure 8: Credit ratings of securities denominated in EUR

$70 \%$

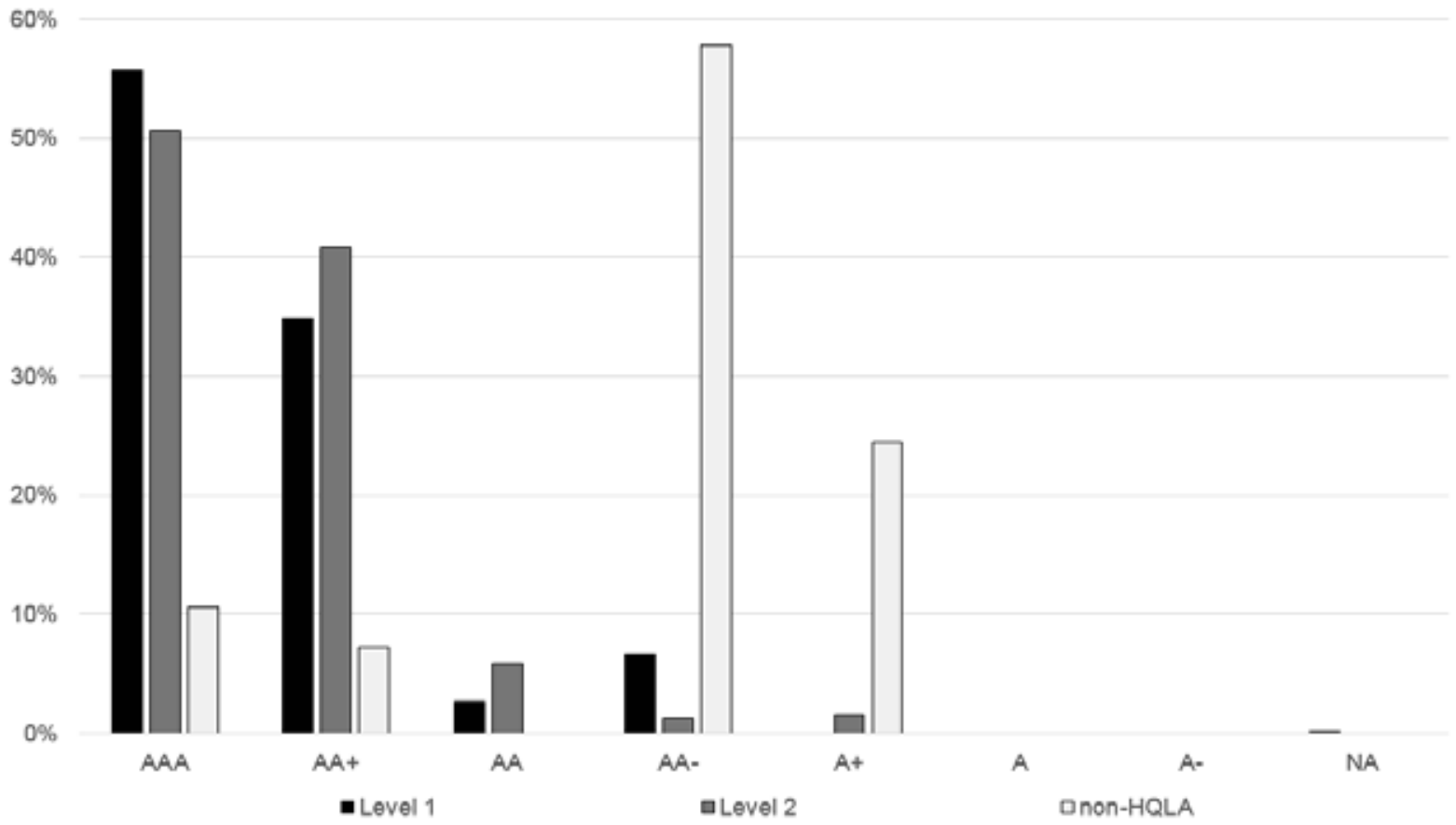

Figure 8 shows the volume-weighted share of securities by credit rating for Level 1, Level 2 and non-HQLA securities denominated in EUR. The black bars show Level 1 securities, the dark gray bars represent Level 2 securities, and the light gray bars show non-HQLA securities. The second-best rating from Moody's, S\&P and Fitch as of 7 July 2014 is used for each security (note that if there is only one rating available, this rating is used). 
Figure 9: Outstanding volume

\section{$\mathrm{CHF}$ bn}

10

9

8

7

5

4

3

2

1

0

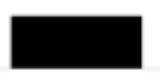

$\mathrm{CHF}$

- Level 1

aLevel 2
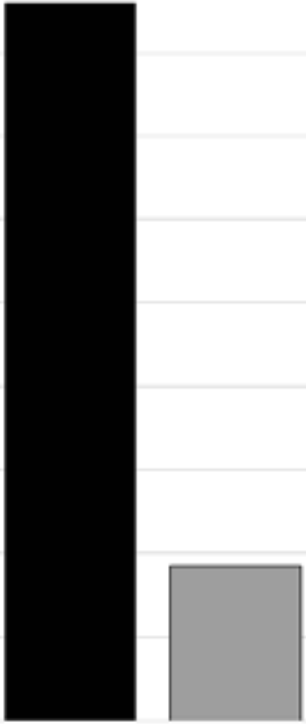

EUR

anon-HQLA

Figure 9 shows the average outstanding volume for Level 1, Level 2 and non-HQLA securities denominated in CHF (left bars) and EUR (right bars) as of 7 July 2014. Amounts are in billion CHF. The outstanding volume of EUR denominated bonds is converted to CHF using a EURCHF exchange rate of 1.0922 (8 March 2016). The black bars show the average outstanding volume of Level 1 securities, the dark gray bars represent the average outstanding volume for Level 2 securities, and the light gray bars show the average outstanding volume for non-HQLA securities. 
Figure 10: Yield curves
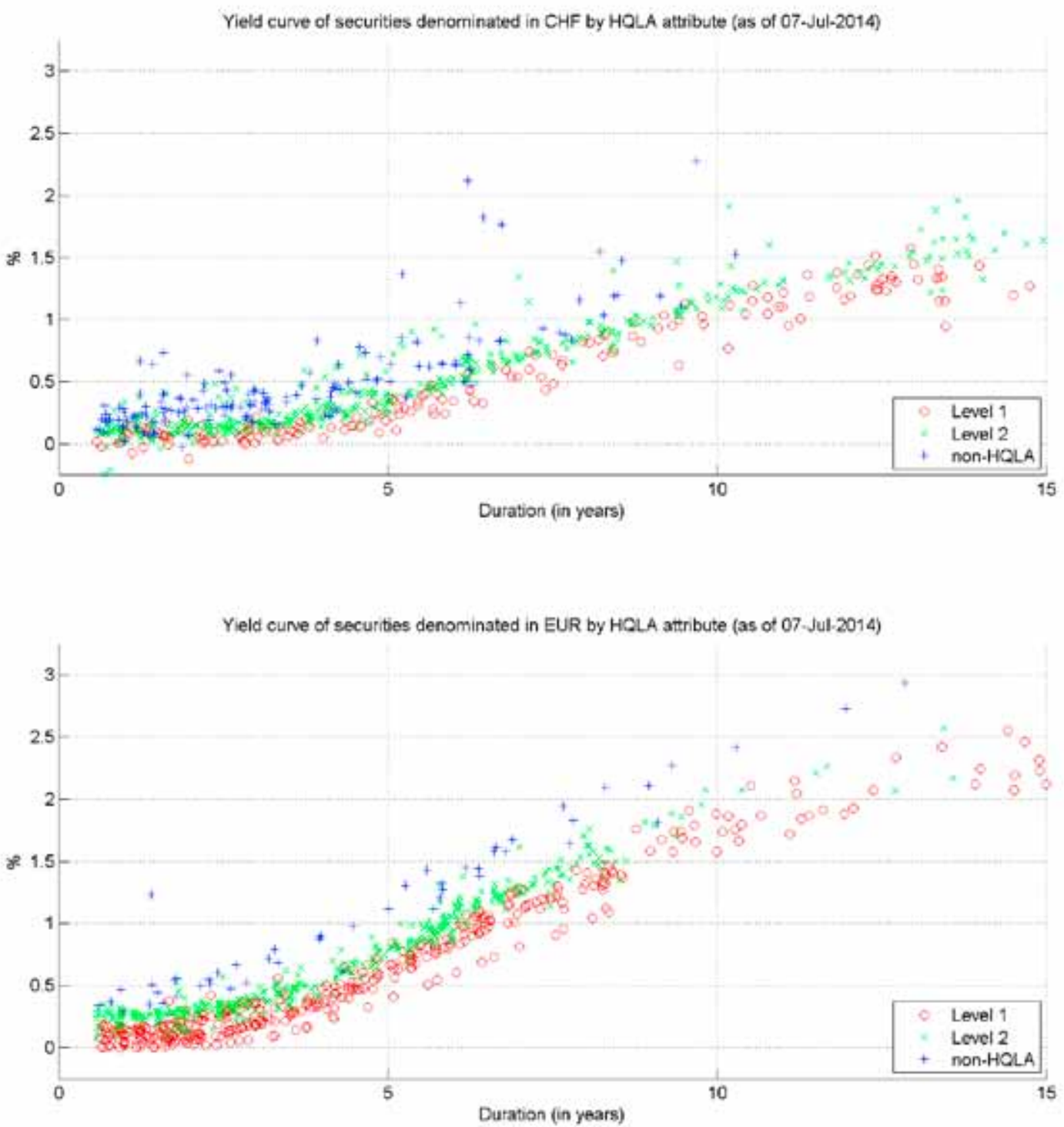

Figure 10 depicts the yield (y-axis) and the duration (in years; $\mathrm{x}$-axis) for each security in our sample as of 7 July 2014 (note that the general shape of the yield curves is very similar, irrespective of the date considered). The red dots represent Level 1 securities, the green crosses Level 2 securities, and the blue "plus" signs non-HQLA securities. Securities denominated in CHF (EUR) are depicted in the upper (lower) part of the figure. Securities with a duration of more than 15 years are not depicted. 
Figure 11: Yield development of securities denominated EUR

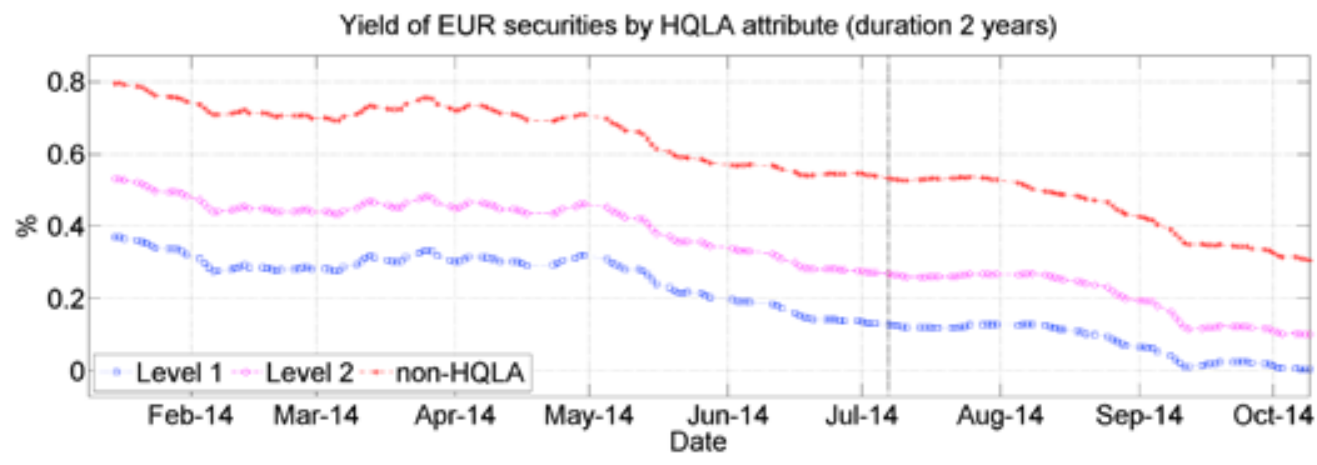

Yield of EUR securities by HQLA attribute (duration 3 years)
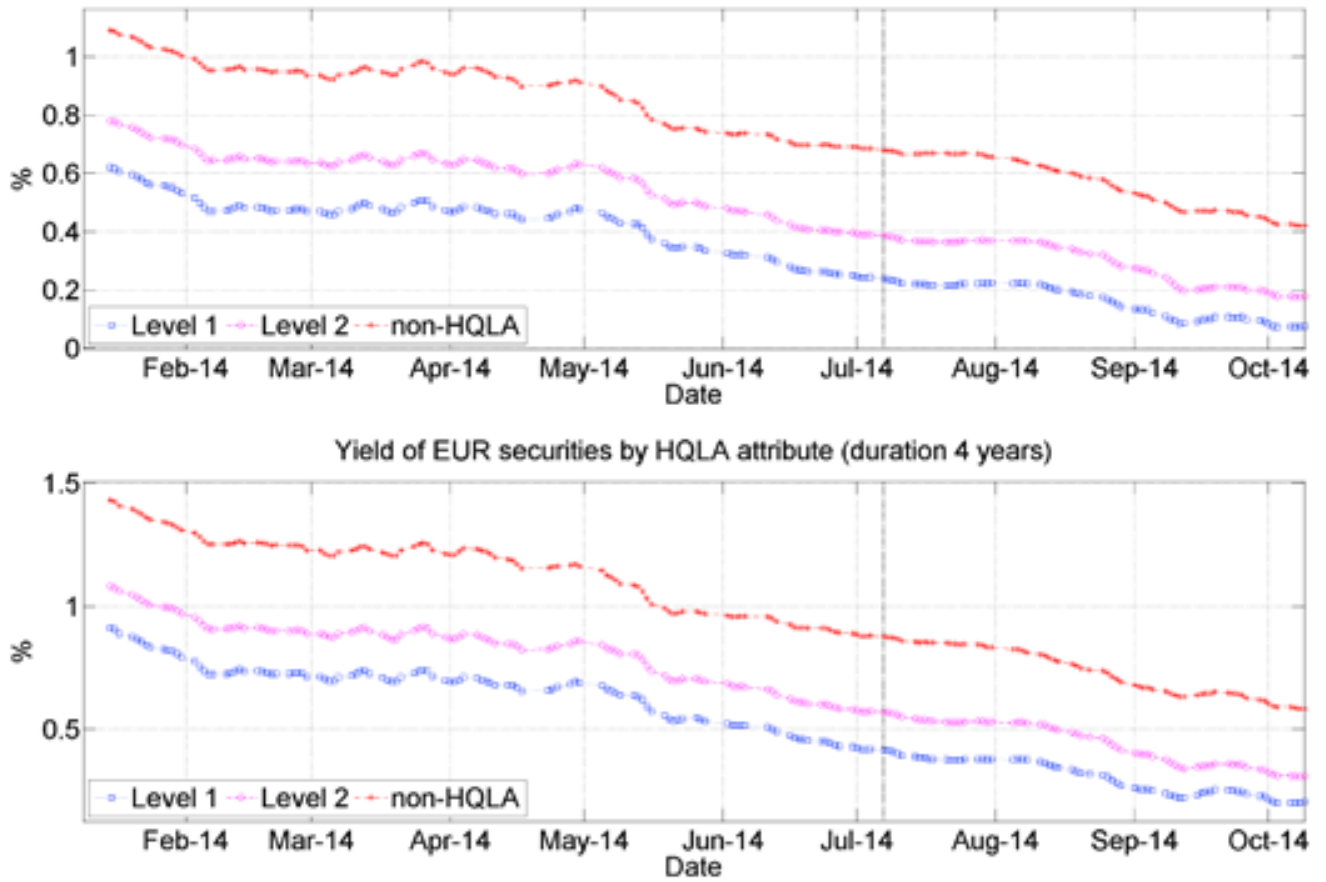

Figure 11 shows rolling one-week moving averages of generic yields with a constant duration of two, three and four years for securities denominated in EUR. Level 1 securities are represented by the blue squares, Level 2 securities by pink dots and non-HQLA securities by red crosses. The vertical lines represent the announcement days of the regulatory change in Switzerland (7 July 2014) and in the European Union (10 October 2014). Generic yields with a constant duration are calculated via the daily estimation of a yield curve for Level 1, Level 2 and non-HQLA securities in EUR using polynomic interpolation (with five degrees). 
Figure 12: Yield development of securities denominated in CHF

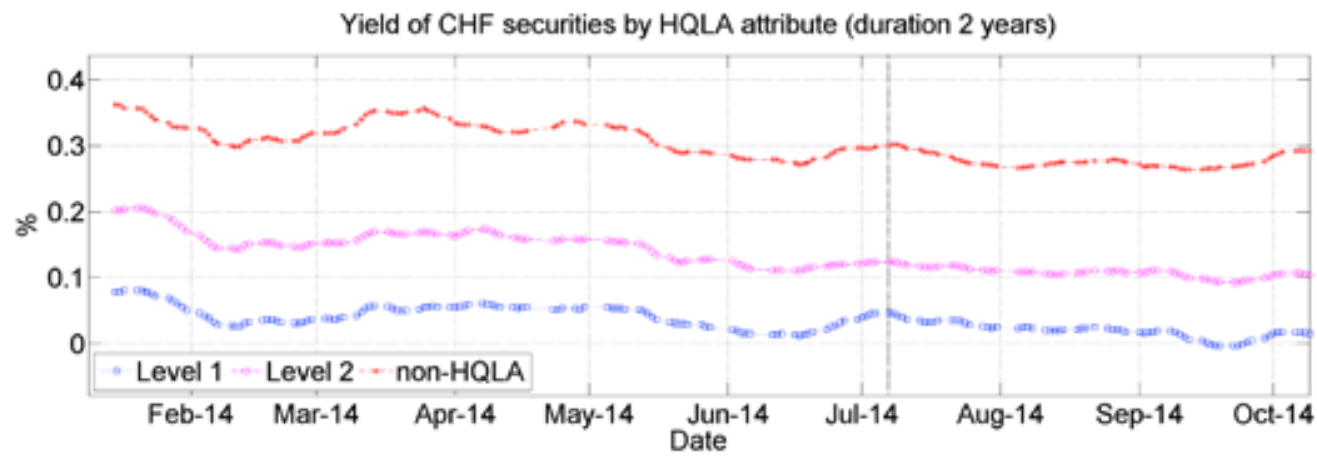

Yield of CHF securities by HQLA attribute (duration 3 years)

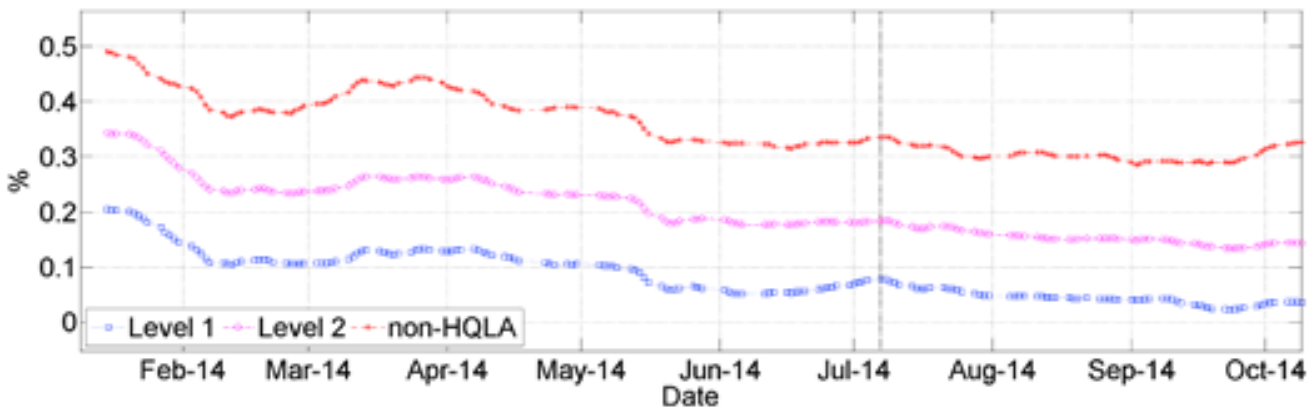

Yield of CHF securities by HQLA attribute (duration 4 years)

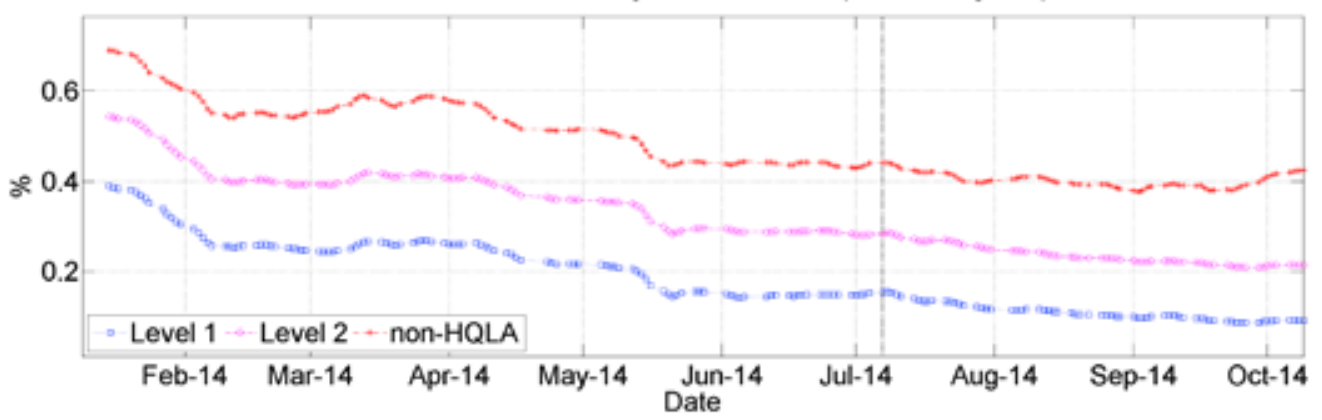

Figure 12 shows rolling one-week moving averages of generic yields with a constant duration of two, three and four years for securities denominated in CHF. Level 1 securities are represented by the blue squares, Level 2 securities by pink dots and non-HQLA securities by red crosses. The vertical lines represent the announcement days of the regulatory change in Switzerland (7 July 2014) and in the European Union (10 October 2014). Generic yields with a constant duration are calculated via the daily estimation of a yield curve for Level 1, Level 2 and non-HQLA securities in CHF using polynomic interpolation (with five degrees). 


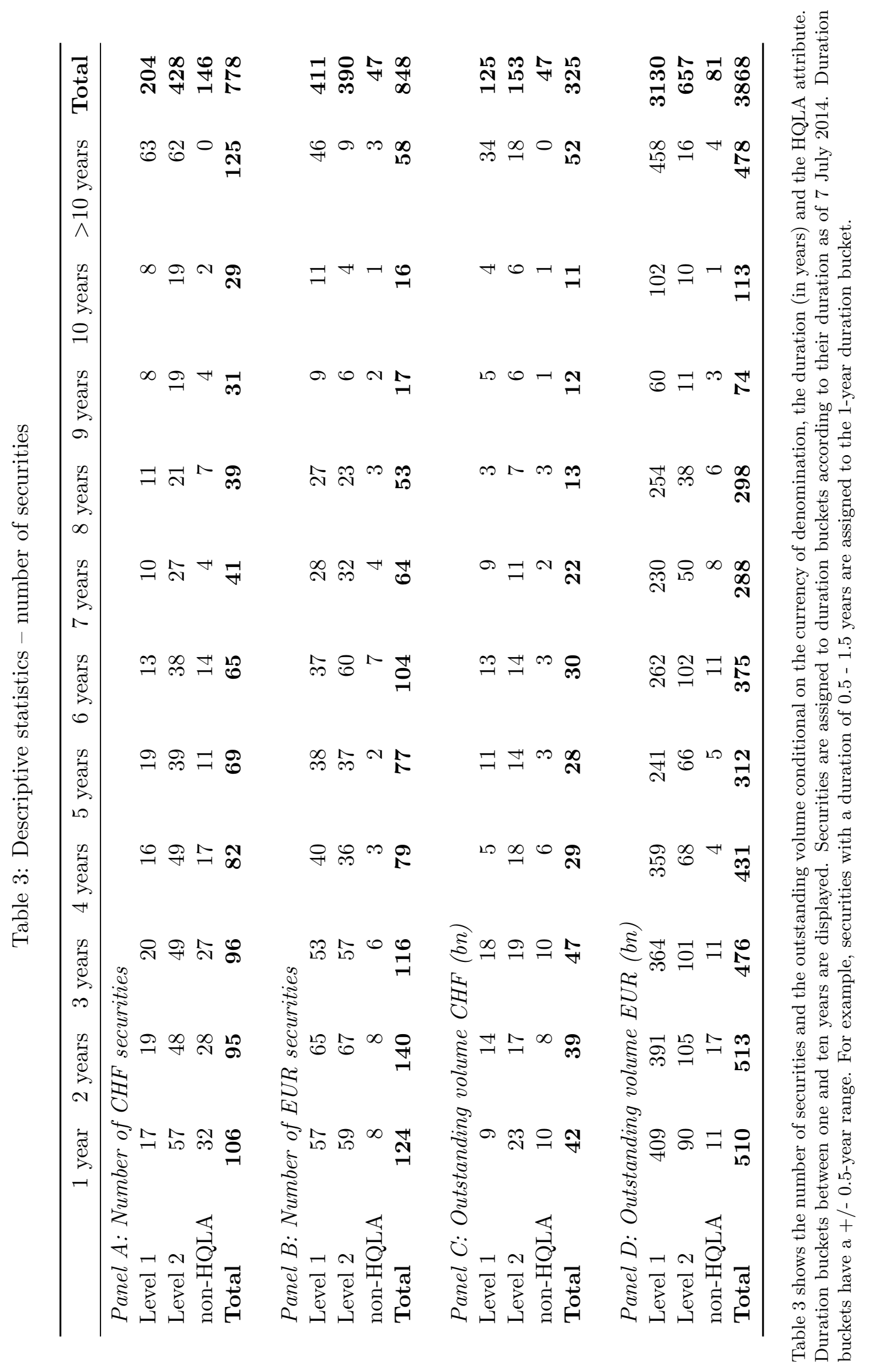




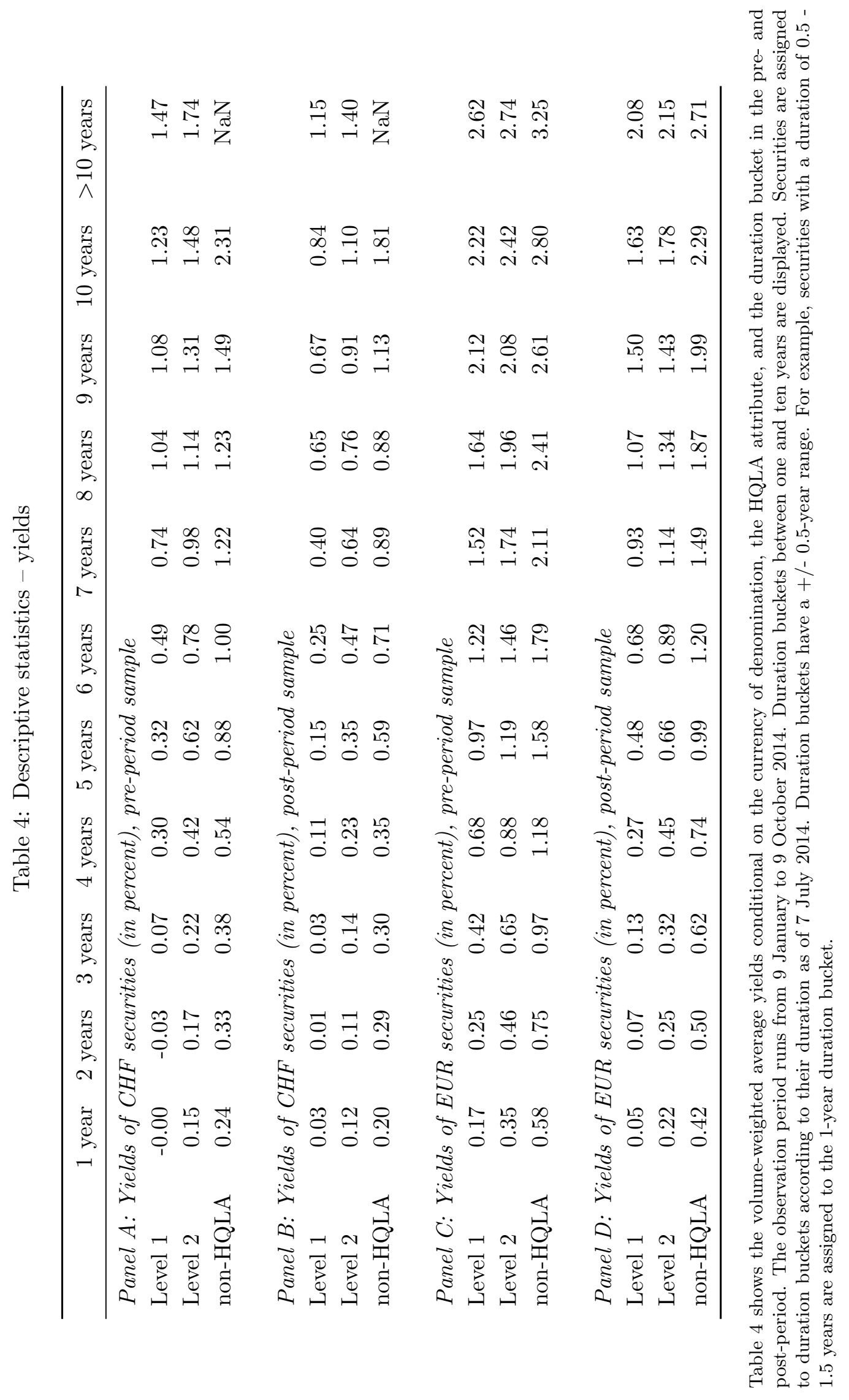




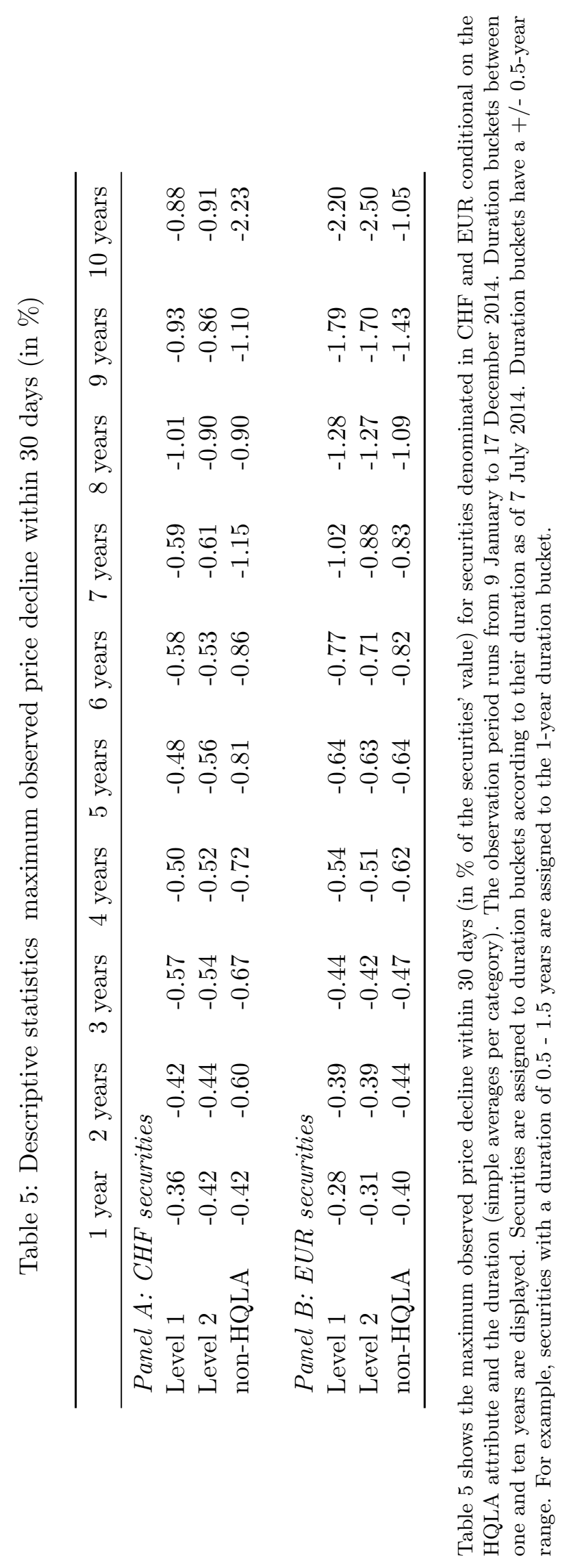




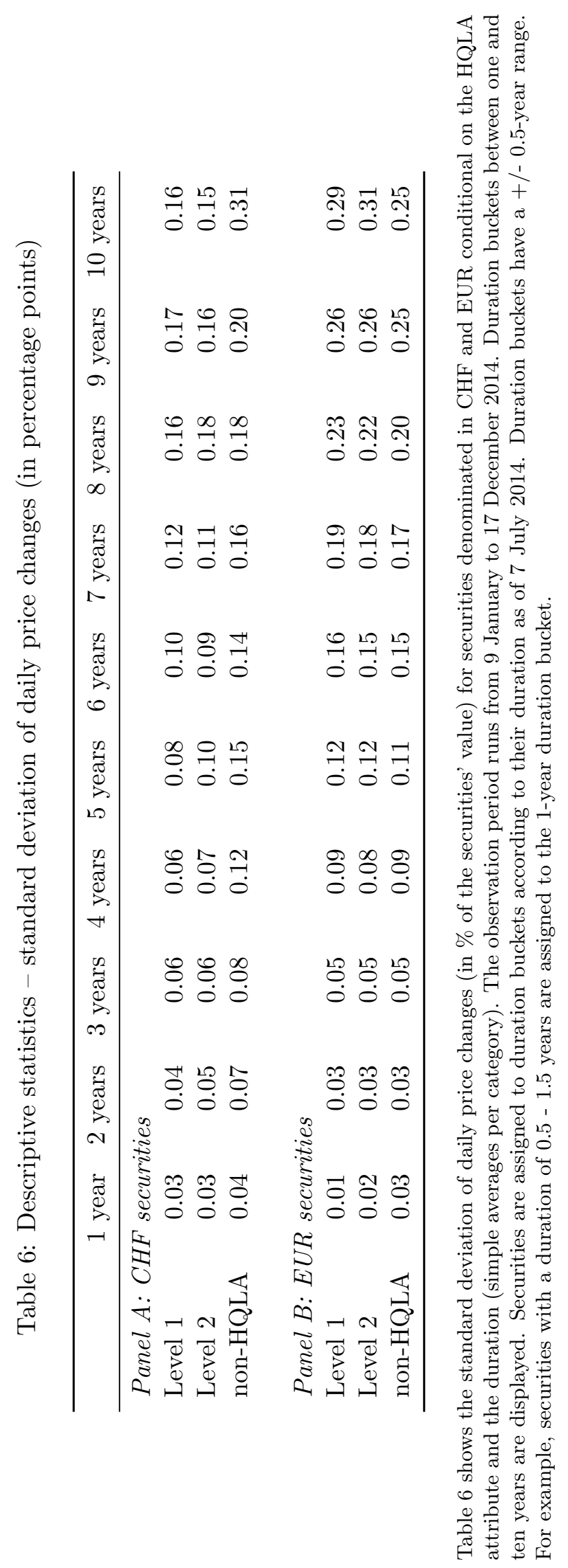


Table 7: Dummy variables in regression analysis

\begin{tabular}{lcccccc}
\hline \hline & \multicolumn{2}{c}{ Level 1 } & \multicolumn{2}{c}{ Level 2 } & \multicolumn{2}{c}{ non-HQLA } \\
Dummy variables & EUR & CHF & EUR & CHF & EUR & CHF \\
\hline Level 2 & & & 1 & 1 & & \\
non-HQLA & & & & & 1 & 1 \\
CHF & & 1 & & 1 & & 1 \\
CHF x Level 2 & & & & 1 & & \\
CHF x non-HQLA & & & & & & 1 \\
const. & 1 & 1 & 1 & 1 & 1 & 1 \\
\hline
\end{tabular}

Table 7 exemplifies the use of dummy variables (rows) in the regression specification including Level 2 securities, given the securities' HQLA attributes as well as the currency of denomination (columns). 
Table 8: Alternative econometric specification - HQLA spreads (coefficients are in percentage points)

\begin{tabular}{lcc}
\hline \hline & $(1)$ & $(2)$ \\
& HQLA spreads & HQLA spreads \\
\hline CHF x Post & $0.0612^{* * *}$ & $0.0612^{* * *}$ \\
& $(22.80)$ & $(12.21)$ \\
Post & $-0.0413^{* * *}$ & $-0.0413^{* * *}$ \\
& $(-20.40)$ & $(-10.89)$ \\
CHF & $-0.141^{* * *}$ & $-0.141^{* * *}$ \\
& $(-89.93)$ & $(-48.30)$ \\
Constant & $0.325^{* * *}$ & $0.325^{* * *}$ \\
& $(128.48)$ & $(68.81)$ \\
\hline Observations & 3680 & 3680 \\
Adjusted $R^{2}$ & 0.906 & 0.906 \\
Duration FE & Yes & Yes \\
SE & Robust & Newey-West $(4)$ \\
\hline \hline$t$ statistics in parentheses \\
${ }^{*} p<0.10,{ }^{* *} p<0.05,{ }^{* * *} p<0.01$
\end{tabular}

Table 8 shows the regression results of a difference-in-difference analysis of HQLA spreads denominated in CHF and EUR with generic duration of one to ten years (as illustrated in Figure 5). Coefficients are in percentage points. The dependent variable is the yield spread between non-HQLA and Level 1 securities denominated in CHF and EUR with a generic duration $j$. Both regression specifications contain duration fixed effects dummy variables. The regression specification is given in Equation (4). The pre-period sample runs from 9 January to 6 July 2014. The post-period sample lasts from 7 July to 9 October $2014 .{ }^{* * *},{ }^{* *}$ and ${ }^{*}$ denote statistical significance (two-tailed) at the $1 \%, 5 \%$, and $10 \%$ significance level, respectively. Column (1) reports Huber-White corrected standard errors and Column (2) Newey-West standard errors. For Newey-West standard errors, the number of lags is set more conservative than suggested by Greene (2003) to the rounded up integer to the fourth root of the number of time series observations (indicated by the number in brackets). 
Table 9: Alternative econometric specification - term structure (coefficients are in percentage points)

\begin{tabular}{|c|c|c|c|c|c|c|}
\hline & $\begin{array}{c}(1) \\
\text { Baseline }\end{array}$ & $\begin{array}{c}(2) \\
\text { Check I }\end{array}$ & $\begin{array}{c}(3) \\
\text { Check II }\end{array}$ & $\begin{array}{c}(4) \\
\text { Check III }\end{array}$ & $\begin{array}{c}(5) \\
\text { Check IV }\end{array}$ & $\begin{array}{c}(6) \\
\text { Check V }\end{array}$ \\
\hline CHF x non-HQLA & $\begin{array}{c}0.0387^{* *} \\
(2.53)\end{array}$ & $\begin{array}{c}0.0421^{* *} \\
(2.32)\end{array}$ & $\begin{array}{c}0.0421^{* *} \\
(2.26)\end{array}$ & $\begin{array}{c}0.0401^{* * *} \\
(2.63)\end{array}$ & $\begin{array}{c}0.0396^{* *} \\
(2.56)\end{array}$ & $\begin{array}{c}0.0412^{* * *} \\
(3.00)\end{array}$ \\
\hline non-HQLA & $\begin{array}{c}-0.0576^{* * *} \\
(-4.52)\end{array}$ & $\begin{array}{c}-0.0615^{* * *} \\
(-3.85)\end{array}$ & $\begin{array}{c}-0.0608^{* * *} \\
(-3.71)\end{array}$ & $\begin{array}{c}-0.0586^{* * *} \\
(-4.61)\end{array}$ & $\begin{array}{c}-0.0582^{* * *} \\
(-4.51)\end{array}$ & $\begin{array}{c}-0.0569^{* * *} \\
(-5.33)\end{array}$ \\
\hline $\mathrm{CHF}$ & $\begin{array}{c}0.150^{* * *} \\
(9.31)\end{array}$ & $\begin{array}{c}0.219^{* * *} \\
(10.22)\end{array}$ & $\begin{array}{c}0.193^{* * *} \\
(6.95)\end{array}$ & $\begin{array}{c}0.142^{* * *} \\
(8.46)\end{array}$ & $\begin{array}{c}0.160^{* * *} \\
(10.23)\end{array}$ & $\begin{array}{c}0.0857^{* * *} \\
(5.47)\end{array}$ \\
\hline Duration (EUR) & $\begin{array}{c}-0.101^{* * *} \\
(-21.16)\end{array}$ & & & $\begin{array}{c}-0.105^{* * *} \\
(-21.49)\end{array}$ & $\begin{array}{c}-0.0962^{* * *} \\
(-18.67)\end{array}$ & $\begin{array}{c}-0.161^{* * *} \\
(-42.62)\end{array}$ \\
\hline Duration $(\mathrm{CHF})$ & $\begin{array}{c}-0.0795^{* * *} \\
(-21.07)\end{array}$ & & & $\begin{array}{c}-0.0812^{* * *} \\
(-21.15)\end{array}$ & $\begin{array}{c}-0.0772^{* * *} \\
(-21.32)\end{array}$ & $\begin{array}{c}-0.101^{* * *} \\
(-15.11)\end{array}$ \\
\hline Duration $^{2}(\mathrm{EUR})$ & $\begin{array}{c}0.00382^{* * *} \\
(12.13)\end{array}$ & & & $\begin{array}{c}0.00401^{* * *} \\
(12.43)\end{array}$ & $\begin{array}{c}0.00360^{* * *} \\
(10.50)\end{array}$ & $\begin{array}{c}0.0114^{* * *} \\
(25.47)\end{array}$ \\
\hline Duration $^{2}(\mathrm{CHF})$ & $\begin{array}{c}0.00311^{* * *} \\
(13.45)\end{array}$ & & & $\begin{array}{c}0.00316^{* * *} \\
(13.63)\end{array}$ & $\begin{array}{c}0.00306^{* * *} \\
(13.45)\end{array}$ & $\begin{array}{c}0.00580^{* * *} \\
(6.65)\end{array}$ \\
\hline Maturity (CHF) & & $\begin{array}{c}-0.0600^{* * *} \\
(-12.89)\end{array}$ & $\begin{array}{c}-0.0591^{* * *} \\
(-12.55)\end{array}$ & & & \\
\hline Maturity (EUR) & & $\begin{array}{c}-0.0556^{* * *} \\
(-11.46)\end{array}$ & $\begin{array}{c}-0.0555^{* * *} \\
(-11.30)\end{array}$ & & & \\
\hline Maturity $^{2}(\mathrm{CHF})$ & & $\begin{array}{c}0.00186^{* * *} \\
(8.00)\end{array}$ & $\begin{array}{c}0.00183^{* * *} \\
(7.83)\end{array}$ & & & \\
\hline Maturity $^{2}(\mathrm{EUR})$ & & $\begin{array}{c}0.00126^{* * *} \\
\quad(6.14)\end{array}$ & $\begin{array}{l}0.00126^{* * *} \\
\quad(6.10)\end{array}$ & & & \\
\hline Coupon EUR & & & $\begin{array}{c}-0.000711 \\
(-0.21)\end{array}$ & & & \\
\hline Coupon CHF & & & $\begin{array}{c}0.00953 \\
(1.53)\end{array}$ & & & \\
\hline $\operatorname{Duration}^{3}(\mathrm{EUR})$ & & & & & & $\begin{array}{c}-0.000242^{* * *} \\
(-16.88)\end{array}$ \\
\hline $\operatorname{Duration}^{3}(\mathrm{CHF})$ & & & & & & $\begin{array}{c}-0.0000845^{* * *} \\
(-2.83)\end{array}$ \\
\hline Constant & $\begin{array}{c}-0.0678^{* * *} \\
(-5.89)\end{array}$ & $\begin{array}{c}-0.176^{* * *} \\
(-11.28)\end{array}$ & $\begin{array}{c}-0.175^{* * *} \\
(-10.47)\end{array}$ & $\begin{array}{c}-0.0466^{* * *} \\
(-3.86)\end{array}$ & $\begin{array}{c}-0.0986^{* * *} \\
(-8.45)\end{array}$ & $\begin{array}{c}0.0314^{* * *} \\
(4.25)\end{array}$ \\
\hline Observations & 822 & 822 & 822 & 822 & 822 & 822 \\
\hline Adjusted $R^{2}$ & 0.857 & 0.768 & 0.768 & 0.860 & 0.853 & 0.889 \\
\hline Duration/Maturity as of: & $7 \mathrm{Jul} 14$ & 7 Jul 14 & 7 Jul 14 & 9 May 14 & 10 Oct 14 & 7 Jul 14 \\
\hline
\end{tabular}

Table 9 shows our baseline regression results (Column (1)) as well as applied robustness tests for possible term structure specifications (Column $(2-6)$ ). Column (2) shows the regression results when using the securities' residual maturity instead of the duration to control for the term structure of interest rates, whereas in Column (3), we additionally control for the securities' coupon. Column (4) and (5) display the regression results when using the duration of securities as of 9 May respectively 10 October instead of the 7 July 2014. Finally, Column (6) reports the regression results when including an additional cubic term to control for the term structure of interest rates into our baseline regression model. The dependent variable is the absolute yield change between the average yield post and pre $\left(\left(\bar{y}^{\text {Post }}-\bar{y}^{\text {Pre }}\right)_{i}\right)$ the regulatory change (7 July 2014) for each individual security $(i)$. The regression specification is given in Equation (3). The pre-period sample runs from 9 January to 6 July 2014. The post-period sample lasts from 7 July to 9 October 2014. Huber-White corrected standard errors are used. $* * *, * *$ and $*$ denote statistical significance (two-tailed) at the $1 \%, 5 \%$, and $10 \%$ significance level, respectively. t-statistics are in parentheses below the coefficients. 
Table 10: Alternative econometric specification - CHF HQLA spreads (coefficients are in percentage points)

\begin{tabular}{lcc}
\hline \hline & $(1)$ & $(2)$ \\
& HQLA spreads & HQLA spreads \\
\hline Post & $0.0198^{* * *}$ & $0.0201^{* * *}$ \\
& $(8.56)$ & $(8.82)$ \\
VIX & & $0.000893^{*}$ \\
& & $(1.83)$ \\
Constant & $0.154^{* * *}$ & $0.142^{* * *}$ \\
& $(33.56)$ & $(18.16)$ \\
\hline Observations & 1840 & 1840 \\
Adjusted $R^{2}$ & 0.958 & 0.958 \\
Duration FE & Yes & Yes \\
SE & Newey-West $(4)$ & Newey-West $(4)$ \\
\hline \hline$t$ statistics in parentheses \\
${ }^{*} p<0.10,{ }^{* *} p<0.05,{ }^{* * *} p<0.01$
\end{tabular}

Table 10 shows the regression results when using HQLA spreads denominated in CHF with duration of one to ten years (as illustrated in Figure 12), only. Column (1) shows the results when regressing the HQLA spreads on a post-period sample dummy. In Column (2), we additionally show the results when including the CBOE Volatility Index (VIX) as a control variable. Both regression specifications contain duration fixed effects dummy variables. The regression specification is as follows: $\operatorname{spread}_{j, t}=\alpha_{j}+\beta_{1}$ Post $_{j, t}+\beta_{2} \operatorname{VIX}_{j, t}+\epsilon_{j, t}$, where the control variable (VIX) is only included in the regression specification of Column (2). The pre-period sample runs from 9 January to 6 July 2014. The post-period sample lasts from 7 July to 9 October 2014. ***, ** and ${ }^{*}$ denote statistical significance (two-tailed) at the 1\%, 5\%, and $10 \%$ significance level, respectively. Newey-West standard errors are reported. For Newey-West standard errors, the number of lags is set more conservative than suggested by Greene (2003) to the rounded up integer to the fourth root of the number of time series observations (indicated by the number in brackets). Coefficients are in percentage points. 


\section{Recent SNB Working Papers}

2016-11 Lucas Marc Fuhrer, Benjamin Müller and Luzian Steiner: The Liquidity Coverage Ratio and Security Prices.

2016-10 Nikola Mirkov, Igor Pozdeev and Paul Söderlind: Toward Removal of the Swiss Franc Cap: Market Expectations and Verbal Interventions.

2016-9 Severin Bernhard and Till Ebner: Cross-border Spill over Effects of Unconventional Monetary Policieson Swiss Asset Prices.

2016-8 Pinar Yeşin: Capital Flows and the Swiss Franc.

2016-7 Signe Krogstrup and Cédric Tille: On the roles of different foreign currencies in European bank lending.

2016-6 Pascal Towbin and Sebastian Weber: Price expectations and the US housing boom.

2016-5 Raphael A. Auer and Cédric Tille: The banking sector and the Swiss financial account during the financial and European debt crises.

2016-4 Christian Hepenstrick and Massimiliano Marcellino: Forecasting with Large Unbalanced Datasets: The Mixed-Frequency Three-Pass Regression Filter.

2016-3 Alain Galli: How reliable are cointegration-based estimates for wealth effects on consumption? Evidence from Switzerland.

2016-2 Pinar Yeşin: Exchange Rate Predictability and State-ofthe-Art Models.
2016-1 Sandra Hanslin and Rolf Scheufele: Foreign PMls: A reliable indicator for exports?

2015-13 Thomas Nellen: Collateralised liquidity, two-part tariff and settlement coordination.

2015-12 Jacob Gyntelberg, Mico Loretan and Tientip Subhanij: Private information, capital flows, and exchange rates.

2015-11 Philip Sauré: Time-intensive R\&D and unbalanced trade.

2015-10 Nikola Mirkov and Andreas Steinhauer: Ben Bernanke vs. Janet Yellen: Exploring the (a)symmetry of individual and aggregate inflation expectations.

2015-9 Aleksander Berentsen, Sébastien Kraenzlin and Benjamin Müller: Exit Strategies and Trade Dynamics in Repo Markets.

2015-8 Thomas Nitschka: Is there a too-big-to-fail discount in excess returns on German banks' stocks?

2015-7 Alin Marius Andries, Andreas M. Fischer and Pinar Yeşin: The impact of international swap lines on stock returns of banks in emerging markets.

2015-6 Jens H.E. Christensen and Signe Krogstrup: Transmission of Quantitative Easing: The Role of Central Bank Reserves.

2015-5 Petra Gerlach-Kristen and Seán Lyons: Mortgage arrears in Europe: The impact of monetary and macroprudential policies.
From 2015, this publication series will be renamed SNB Working Papers.

All SNB Working Papers are available for download at: www.snb.ch, Research

Subscriptions or individual issues can be ordered at: Swiss National Bank

Library

P.O. Box

$\mathrm{CH}-8022$ Zurich

Phone: +41586311150

Fax: +41586315048

E-mail: library@snb.ch 
